UNIVERSIDADE DE SÃO PAULO

FACULDADE DE ZOOTECNIA E ENGENHARIA DE ALIMENTOS DEPARTAMENTO DE MEDICINA VETERINÁRIA

ELIDIANE RUSCH

EFEITOS DA MORFINA E METADONA SOBRE O COMPORTAMENTO E CRESCIMENTO TUMORAL DE CAMUNDONGOS COM TUMOR DE EHRLICH

PIRASSUNUNGA

2020

ELIDIANE RUSCH 


\section{EFEITOS DA MORFINA E METADONA SOBRE O COMPORTAMENTO E CRESCIMENTO TUMORAL DE CAMUNDONGOS COM TUMOR DE EHRLICH}

\section{Versão corrigida}

Dissertação apresentada à Faculdade de Zootecnia e Engenharia de Alimentos da Universidade de São Paulo, como requisito para a obtenção do Título de "Mestre em Ciências".

Área de Concentração: Biociência Animal

Orientador: Prof. Dr. Adriano Bonfim Carregaro

Co-orientador: Prof. Dr. Heidge Fukumasu

\section{PIRASSUNUNGA}




\section{UNIVERSIDADE DE SÃO PAULO}

Faculdade de Zootecnia e Engenharia de Alimentos Comitê de Ética em Pesquisa da FZEA

\section{CERTIFICADO}

Certificamos que a proposta intitulada "Avaliação da sedação e analgesia em camundongos com tumor de Ehrlich tratados com morfina ou metadona", protocolada sob o CEUA $n^{\circ} 3836220518$ (ID 001002), sob a responsabilidade de Adriano Bonfim Carregaro e equipe; Daniele dos Santos Martins - que envolve a produção, manutenção e/ou utilização de animais pertencentes ao filo Chordata, subfilo Vertebrata (exceto o homem), para fins de pesquisa científica ou ensino - está de acordo com os preceitos da Lei 11.794 de 8 de outubro de 2008, com o Decreto 6.899 de 15 de julho de 2009 , bem como com as normas editadas pelo Conselho Nacional de Controle da Experimentação Animal (CONCEA), e foi aprovada pela Comissão de Ética no Uso de Animais da Faculdade de Zootecnia e Engenharia de Alimentos da Universidade de São Paulo - FZEA/USP (CEUA/FZEA) na reunião de 22/08/2018.

We certify that the proposal "Evaluation of sedation and analgesia in Ehrlich tumor-treated mice with morphine or methadone", utilizing 56 Isogenics mice (56 females), protocol number CEUA 3836220518 (ID 001002), under the responsibility of Adriano Bonfim Carregaro and team; Daniele dos Santos Martins - which involves the production, maintenance and/or use of animals belonging to the phylum Chordata, subphylum Vertebrata (except human beings), for scientific research purposes or teaching - is in accordance with Law 11.794 of October 8, 2008, Decree 6899 of July 15, 2009, as well as with the rules issued by the National Council for Control of Animal Experimentation (CONCEA), and was approved by the Ethic Committee on Animal Use of the School of Animal Science and Food Engineering - (São Paulo University) (CEUA/FZEA) in the meeting of $08 / 22 / 2018$.

Finalidade da Proposta: Pesquisa

(Acadêmica)

Vigência da Proposta: de 09/2018 a

Área: Medicina Veterinária

$07 / 2019$

Origem: Biotério do CEPTOX

FMVZ/USP Espécie: Camundongos

isogênicos

Linhagem: Balb/c

sexo: Fêmeas

idade: 50 a 50 dias

N: 56

Local do experimento: Centro de Pesquisa em Toxicologia Veterinária (CPTOX - FZEA).

Pirassununga, 10 de maio de 2020

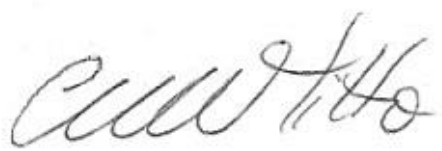

Profa. Dra. Cristiane Gonçalves Titto

Coordenadora da Comissão de Ética no Uso de Animais Animais

Faculdade de Zootecnia e Engenharia de Alimentos da Universidade de São Paulo FZEA/USP
Peso: 25 a $30 \mathrm{~g}$ 


\section{CERTIFICADO}

Certificamos que a proposta intitulada "Influência da morfina e metadona sobre a imunomodulação em camundongos Balb/c com tumor de Ehrlich", protocolada sob o CEUA n 3352010818 (ID 001038), sob a responsabilidade de Adriano Bonfim Carregaro - que envolve a produção, manutenção e/ou utilização de animais pertencentes ao filo Chordata, subfilo Vertebrata (exceto o homem), para fins de pesquisa científica ou ensino - está de acordo com os preceitos da Lei 11.794 de 8 de outubro de 2008, com o Decreto 6.899 de 15 de julho de 2009, bem como com as normas editadas pelo Conselho Nacional de Controle da Experimentação Animal (CONCEA), e foi aprovada pela Comissão de Ética no Uso de Animais da Faculdade de Zootecnia e Engenharia de Alimentos da Universidade de São Paulo - FZEA/USP (CEUA/FZEA) na reunião de $17 / 10 / 2018$.

We certify that the proposal "Influence of morphine and methadone on immunomodulation in Balb/c mice with Ehrlich tumor", utilizing 82 Isogenics mice (82 females), protocol number CEUA 3352010818 (ID 001038), under the responsibility of Adriano Bonfim Carregaro - which involves the production, maintenance and/or use of animals belonging to the phylum Chordata, subphylum Vertebrata (except human beings), for scientific research purposes or teaching - is in accordance with Law 11.794 of October 8,2008 , Decree 6899 of July 15,2009 , as well as with the rules issued by the National Council for Control of Animal Experimentation (CONCEA), and was approved by the Ethic Committee on Animal Use of the School of Animal Science and Food Engineering - (São Paulo University) (CEUA/FZEA) in the meeting of 10/17/2018.

Finalidade da Proposta: Pesquisa

(Acadêmica)

Vigência da Proposta: de 08/2018 a

Área: Medicina Veterinária

07/2019

Origem: Biotério do CEPTOX

FMVZ/USP Espécie: Camundongos

isogênicos

Linhagem: Balb/c

sexo: Fêmeas

idade: 45 a 70 dias

N: 82

Local do experimento: Centro de Pesquisa em Toxic ologia Veterinária (CPTOX - FZEA)

Peso: 25 a $30 \mathrm{~g}$

Pirassununga, 10 de maio de 2020

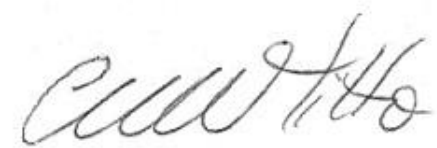

Profa. Dra. Cristiane Gonçalves Titto Coordenadora da Comissão de Ética no Uso de Animais Animais

Faculdade de Zootecnia e Engenharia de Alimentos da Universidade de São Paulo FZEA/USP

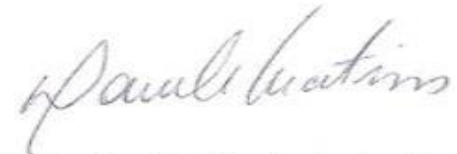

Profa. Dra. Daniele dos Santos Martins Vice-Coordenadora da Comissão de Ética no Uso de

Faculdade de Zootecnia e Engenharia de Alimentos da Universidade de São Paulo - FZEA/USP 
Ficha catalográfica elaborada pelo

Serviço de Biblioteca e Informação, FZEA/USP, com os dados fornecidos pelo(a) autor(a)

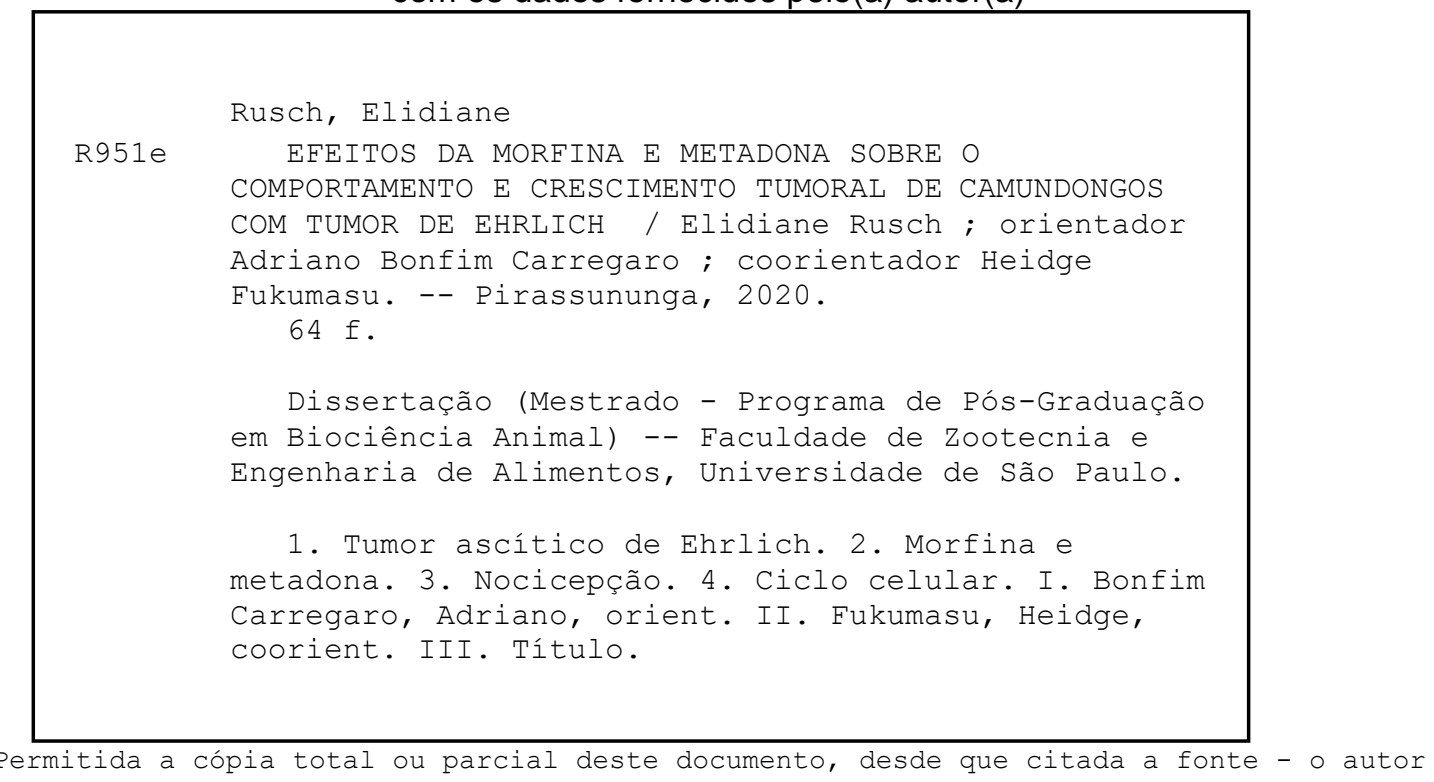




\title{
EFEITOS DA MORFINA E METADONA SOBRE O COMPORTAMENTO E CRESCIMENTO TUMORAL DE CAMUNDONGOS COM TUMOR DE EHRLICH
}

\author{
Dissertação apresentada à Faculdade de \\ Zootecnia e Engenharia de Alimentos da \\ Universidade de São Paulo, como parte dos \\ requisitos para a obtenção do Título de Mestre \\ em Ciências.
}

Área de Concentração: Biociência Animal

Data de aprovação:

Banca Examinadora:

Prof. Dr.

Instituição

Presidente da Banca Examinadora

Prof.(a) Dr.(a) Instituição

Prof.(a) Dr.(a) Instituição

Prof.(a) Dr.(a) Instituição 
Qos meus pais, que sempre serãa minha fonk de inspiração e porto seguro. Agradeço pelo amor e pelo apoio em todos as momentos da minha vida. Obrigada por me fazerem acreditar que tuda é possível com coragem e força de vontade. Dedico esse trabaltho a vocês. 


\section{AGRADECIMENTOS}

À Deus, pela vida, pela oportunidade, pela saúde e por ter colocado pessoas tão especiais na minha vida. Que Ele continue nos abençoando.

Aos meus pais, que mesmo sabendo da distância e da dificuldade de ficar longe, apoiaram a ideia da realização desse trabalho até o fim. Agradeço de coração pelo amor incondicional, pelo apoio em todas as horas, mesmo que em algumas fossem vocês quem precisassem...

À minha família, vó Elvira, vô Arcelino, Luana, Sadi, Geni, aos tios. Obrigada pelo apoio incondicional.

Aos mestres. Ao Doutor Adriano Carregaro que aceitou essa empreitada de orientação e que mesmo de longe fez o melhor que pôde para que o trabalho fosse executado. Sua orientação e disponibilidade foram fundamentais para a elaboração desse projeto. Obrigada pela sua extrema atenção, dedicação, paciência, senso crítico, amizade e confiança ao longo desses anos. Sou eternamente grata pela oportunidade de ter sido sua orientada. Você é e sempre será um grande exemplo para mim.

Ao Doutor Heidge Fukumasu pela ajuda em todos os momentos, desde a consolidação da ideia, até a execução do trabalho. Obrigada também pelos conselhos.

Ao Rogian pelo companheirismo. Obrigada por ter me acompanhado nessa jornada.

A minha amiga Patricia, que me acompanhou durante toda a jornada. A Marilia e Pedro pelo companheirismo pessoal e profissional, pelos churrascos, pipocas, anestesias a campo e experimentos, o apoio de vocês foi incondicional. A Milena, pela ajuda, apoio e amizade desde o tempo do estágio até o experimento do mestrado. Obrigada de coração. Ao Jeff, pelos conselhos, pelas enzimas, pelos cafés da tarde e por toda a ajuda sempre. Mariana Sanches pelas viagens, anestesias e ensinamentos. A Thais pelos conselhos, almoços e companheirismo ao longo desses anos. A Nathalia pelos cafés da manhã e da tarde que ficarão para sempre em meu coração. A Bruna, pela paciência desde o estágio, tenho uma enorme admiração por você. Aos queridos Amanda, Thais Macedo, Julia, Roberto, Angélica, Marianna, Mayara, Leticia, Thami e Wellignton. Todos vocês são minha inspiração diária, aprendi muito com vocês! Tenham certeza que levarei vocês para sempre em meu coração. Sinto grande felicidade por ter conhecido vocês.

A Valéria, agradeço pela confiança, conselhos e amizade durante esse tempo que permaneci em Pirassununga.

Ao NAVE de maneira geral. 
Aos queridos amigos do CEPTOX, Ester, Elaine, Paulo, Claudia e à Lígia por ceder seu laboratório quando os equipamentos não funcionaram.

Ao LOCT, especialmente Arina, Dani e Jéssika.

A FZEA pela oportunidade.

A CAPES pela bolsa de estudos.

De coração, agradeço a todos aqueles que cruzaram meu caminho nesses dois anos e meio de mestrado e fizeram com que o percurso fosse mais fácil de ser realizado. Sem vocês, eu nada seria. 
"Para conseguir o que quer, você deve olhar além do que você vê". (Walt Disney). 


\section{RESUMO}

RUSCH, E. Efeitos da morfina e metadona sobre o comportamento e crescimento tumoral de camundongos com tumor de Ehrlich. 2020. Dissertação (Mestrado). Faculdade de Zootecnia e Engenharia de Alimentos, Universidade de São Paulo, Pirassununga, 2020.

A morfina e a metadona, embora sejam fármacos recomendados para promover analgesia, parecem promover alterações comportamentais e influenciar no crescimento tumoral em modelos experimentais. Diante disso, o objetivo do estudo consistiu em avaliar os efeitos da morfina e metadona sobre o comportamento, antinocicepção e crescimento tumoral em camundongos. O estudo foi dividido em duas partes. No primeiro experimento foram utilizados 53 camundongos, fêmeas, com $60 \pm 10$ dias de idade que foram inoculados com tumor ascítico de Ehrlich (TAE) por via intraperitoneal. Após sete dias da inoculação, os animais foram distribuídos aleatoriamente em 7 grupos, morfina $5 \mathrm{mg} / \mathrm{kg}$ (Morf5), morfina 7,5 $\mathrm{mg} / \mathrm{kg}\left(\operatorname{Morf}_{7,5}\right)$, morfina $10 \mathrm{mg} / \mathrm{kg}$ (Morf 10$)$, metadona 2,85 mg/kg (Met 2,85$)$, metadona 4,3 $\mathrm{mg} / \mathrm{kg}$ (Met 4,3 ), metadona 5,7 mg/kg (Met 5,7 ) e solução salina $\mathrm{NaCl}$ 0,9\% (Salina). Os tratamentos foram administrados por via subcutânea, a cada seis horas, durante três dias. Os animais foram avaliados quanto a atividade geral em campo aberto e nocicepção, por meio do teste de pinçamento de cauda, os quais foram realizados antes da inoculação tumoral (dia 0), aos 40, 90, 150, 240 e 360 minutos após o início dos tratamentos (dia 7) e 40, 150 e 360 minutos após os dias 8 e 9 pós-inoculação. Todas as doses promoveram aumento significativo da distância percorrida e velocidade média de maneira dose-dependente, sendo que os efeitos foram mais pronunciados nos dias 8 e 9. As frequências de levantar e de autolimpeza reduziram de maneira significativa após a administração de morfina e metadona em todas as doses até os 90 minutos. O segundo experimento consistiu em avaliar os efeitos sobre o crescimento tumoral das mesmas doses da morfina e metadona administradas por via subcutânea, a cada 6 horas, durante 8 dias, iniciados 24 horas após a inoculação tumoral. Os animais foram avaliados diariamente quanto ao peso e circunferência abdominal e nove dias após a inoculação tumoral, foram submetidos à eutanásia. O líquido ascítico foi colhido para aferição do volume, verificação da característica do líquido, contagem de células tumorais e análise do ciclo celular. Todos os animais apresentaram aumento de peso e de circunferência abdominal ao longo dos dias. O volume do líquido ascítico peritoneal foi menor nos tratamentos Morf $_{5}$, Morf 10 e em todas as doses testadas de metadona em comparação ao grupo Salina. A viabilidade e o número de células totais não diferiram entre os tratamentos. Os tratamentos Morf 10 e Met5,7 interferiram no ciclo celular das células tumorais com maior porcentagem de células na fase G1 do ciclo, em comparação ao grupo Salina. Observou-se, a partir do primeiro experimento que todas as doses testadas promovem aumento da locomoção e redução de comportamentos exploratórios que foram mais evidentes ao longo dos dias de tratamento. A antinocicepção é observada por até 40 minutos em dose única e prolonga-se por até 150 minutos após administrações seriadas nas doses intermediárias e maiores. Os tratamentos Morf 10 e Met5,7 promovem estase do ciclo celular, mas não interferem de maneira significativa no crescimento do tumor ascítico de Ehrlich.

Palavras-chave: Comportamento exploratório; antinocicepção; opioides; ciclo celular; 


\begin{abstract}
RUSCH, E. Effects of morphine and methadone on the behavior and tumor growth of mice with Ehrlich tumor. 2020. 26 f. M.Sc. Dissertation - Faculdade de Zootecnia e Engenharia de Alimentos, University of Sao Paulo, Pirassununga, 2020.

The objective of this research is to evaluate the effects of morphine and methadone on behavior, antinociception and tumor growth in mice. The study was dived into two parts. In the first experiment, Fifty-three female mice, $60 \pm 10$ days old, were inoculated with Ehrlich's ascitic tumor (EAT) intraperitoneally. Seven days after intraperitoneal tumour inoculation (2 $\times 10^{6}$ cells), the animals were randomised into seven groups: morphine $5 \mathrm{mg} / \mathrm{kg}\left(\mathrm{MO}_{5}\right)$, morphine $7.5 \mathrm{mg} / \mathrm{kg}\left(\mathrm{MO}_{7.5}\right)$, morphine $10 \mathrm{mg} / \mathrm{kg}\left(\mathrm{MO}_{10}\right)$, methadone $2.85 \mathrm{mg} / \mathrm{kg}\left(\mathrm{ME}_{2.85}\right)$, methadone $4.3 \mathrm{mg} / \mathrm{kg}\left(\mathrm{ME}_{4.3}\right)$, methadone $5.7 \mathrm{mg} / \mathrm{kg}\left(\mathrm{ME}_{5.7}\right)$, and $0.9 \% \mathrm{NaCl}$ (Sal). Treatments were administered subcutaneously, every $6 \mathrm{~h}$, for 3 days. The animals were evaluated for general activity and nociception using the open field and tail clip tests, respectively. These tests were performed before tumour inoculation (day 0); at 40, 90, 150, 240, and $360 \mathrm{~min}$ following treatment initiation (day 7); and at 40, 150, and $360 \mathrm{~min}$ after days 8 and 9 post-inoculation. All evaluated doses promoted a significant dose-dependent increase in the total distance travelled and the average speed, markedly pronounced on days 8 and 9 than on day 7 . The frequencies of rearing and self-grooming decreased significantly after morphine or methadone administration. The second experiment consisted of evaluating the effects on tumor growth of the same doses of morphine and methadone administered subcutaneously, every 6 hours, for 8 days, starting 24 hours after tumor inoculation. The animals were evaluated daily for weight and abdominal circumference and they were euthanized nine days after the tumor inoculation. The ascitic fluid was collected to measure the volume, check the characteristic of the liquid, count the tumor cells and analyze the cell cycle. All animals had increased weight and waist circumference over the days. The volume of peritoneal ascitic fluid was lower in the Morf 5 , Morf 10 treatments and in all tested methadone doses compared to the Saline group. Viability and number of total cells did not differ between treatments. Morf 10 and Met 5,7 treatments interfered in the cell cycle of tumor cells, with a higher percentage of cells in the G1 phase of the cycle, compared to the Saline group. It was observed, from the first experiment, that all doses tested promote increased locomotion and reduced exploratory behaviors that were more evident over the treatment days. Antinociception was observed for up to 40 minutes in a single dose and continued for up to 150 minutes after serial administrations in intermediate and higher doses. The Morf 10 and Met 5,7 treatments promoted cell cycle stasis, but did not significantly interfere with the growth of Ehrlich's ascites tumor.
\end{abstract}

Keywords: exploratory behavior; antinociception; opioids; cell cycle. 


\section{LISTA DE FIGURAS}

Figure 5.1. Locomotor activity (distance covered and average speed) over time after repeated administration (every 6 hours) of morphine or methadone in different dosages, for 3 days (day 7,8 and 9 after tumor inoculation). Values are expressed as mean \pm standard deviation $(\mathrm{n}=$ 7). $p<0.05$ compared to the Control group $(*)$ and to baseline values $(\S)$ through the one-way ANOVA test and Dunnet test....................................................... 30

Figure 5.2. Exploratory behavior (rearing frequency and grooming frequency) over time after repeated administration (every 6 hours) of morphine or methadone in different dosages, for 3 days (day 7,8 and 9 after tumor inoculation). Values are expressed as median (interquartile range) $(\mathrm{n}=7) . * p<0.05$ compared to the Control group through the Kruskal-Wallis and Dunn test, and to baseline values $(\S)$ through the Friedman and Dunn tes

Figure 5.3. Response to tail clipping over time after repeated administration (every 6 hours) of morphine or methadone in different dosages, for 3 days (day 7,8 and 9 after tumor inoculation). Values are expressed as median (interquartile range) $(\mathrm{n}=7)$. $* \mathrm{p}<0.05$ compared to the Control group through the Kruskal-Wallis and Dunn test and to baseline values through the Friedman and Dunn

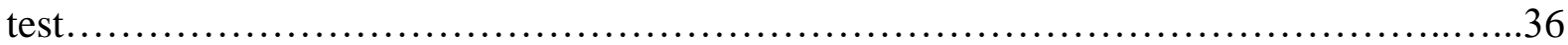

Figura 6.1 - Avaliação do peso (em gramas) e da circunferência abdominal (em centímetros) de camundongos fêmeas BALB/c inoculados com células do carcinoma ascítico de Ehrlich e tratados com $\mathrm{NaCl}$ 0,9\% (Salina), diferentes doses de morfina ou metadona durante oito dias. Valores expressos em média \pm erro padrão $(n=8)$. * Valores considerados diferentes quando comparados ao grupo Salina $(\mathrm{p}<0,05)$

Figura 6.2 - Volume do líquido peritoneal (A), células por $\mathrm{mL}(\mathrm{B})$ e células totais (C) após nove dias de crescimento do tumor ascítico de Ehrlich em camundongos BALB/c tratados com solução salina (Sal), diferentes doses de morfina ou metadona. 49

Figura 6.3 - Porcentagem de células tumorais em fases do ciclo celular G0/G1, S, G2/M, de camundongos submetidos 8 dias após tratamento de morfina e metadona ou solução salina. * $\mathrm{p}<0,05$, ANOVA seguido do teste de Tukey. 


\section{SUMÁRIO}

1 INTRODUÇÃOO 16

2 CARACTERIZAÇÃO DO PROBLEMA 18

3 OBJETIVOS $\quad 24$

3.1 OBJETIVO GERAL $\quad 24$

3.2 OBJETIVOS ESPECÍFICOS 24

4 HIPÓTESES

5 ESTUDO 1 - THREE-DAY CONSECUTIVE ADMINISTRATION OF MORPHINE

OR METHADONE PROMOTES ANTINOCICEPTION AND INCREASES

BEHAVIOURAL ACTIVITY IN MICE WITH EHRLICH CARCINOMA 25

$\begin{array}{ll}\text { ABSTRACT } & 25\end{array}$

5.1 INTRODUCTION 25

5.2 MATERIAL AND METHODS 26

5.2.1 Animals 26

$\begin{array}{ll}\text { 5.2.2 Drugs } & 27\end{array}$

$\begin{array}{ll}\text { 5.2.3 Treatment protocol } & 27\end{array}$

$\begin{array}{ll}\text { 5.2.4 Behavioural tests } & 27\end{array}$

$\begin{array}{ll}\text { 5.2.5 Nociception test } & 28\end{array}$

$\begin{array}{ll}\text { 5.2.6 Statistical analysis } & 28\end{array}$

$\begin{array}{ll}5.3 \text { RESULTS } & 28\end{array}$

5.3.1 Distance travelled $\quad 29$

$\begin{array}{ll}\text { 5.3.2 Average speed } & 31\end{array}$

$\begin{array}{ll}\text { 5.3.3 Rearing frequency } & 31\end{array}$

$\begin{array}{ll}\text { 5.3.4 Frequency of self-grooming } & 34\end{array}$

5.3.5 Tail clip test

$\begin{array}{ll}5.4 \text { DISCUSSION } & 37\end{array}$

5.5 CONCLUSION 39

REFERENCES 39

6. ESTUdO 2 - MORFINA E METADONA NÃO ALTERAM CRESCIMENTO DO TUMOR ASCÍTICO DE EHRLICH EM CAMUNDONGOS 43

RESUMO $\quad 43$

6.1 INTRODUÇÃO $\quad 43$

6.2 MATERIAL E MÉTODOS 45

6.2.1 Animais $\quad 45$

6.2.2 Fármacos $\quad 45$

6.2.3 Desenho experimental $\quad 45$

$\begin{array}{ll}\text { 6.2.4 Análise estatística } & 46\end{array}$

6.3 RESULTADOS $\quad 47$

6.4 DISCUSSÃO $\quad 50$

6.5 CONCLUSÃO $\quad 52$

7 CONCLUSÕES $\quad 55$ 
8 CONSIDERAÇÕES FINAIS

REFERÊNCIAS

APÊNDICE A 


\section{INTRODUÇÃO}

O câncer de mama é o tipo de tumor que mais acomete mulheres no mundo, com estimativa de 66.280 novos casos e morte de cerca de 16.724 mulheres por essa causa no ano de 2020 no Brasil (INCA, 2019). A dor de caráter moderado a severo é detectada nessas pacientes em decorrência do próprio tumor, cirurgias ou tratamentos quimioterápicos, e o seu tratamento inclui a utilização de agonistas opioides potentes (WHO, 2017). Na maioria dos casos, a morfina é eleita como o fármaco de primeira escolha, seguida pela metadona em casos de dependência ou refratariedade à primeira opção (MERCADANTE; BRUERA, 2017).

O estudo da dor em modelos experimentais tem sido crucial para a compreensão dos mecanismos e processos dolorosos (GREGORY et al., 2013). Diferentes modelos são utilizados para representar os diferentes tipos de dor com base no tecido afetado e do mecanismo lesivo (térmico, mecânico, inflamatório, neuropático) (DEUIS; DVORAKOVA; VETTER, 2017). Essas medidas consistem em uma representação clínica das características da dor. O tratamento da dor nesses modelos experimentais é indispensável e frequentemente opioides são recomendados para essa finalidade (GEBHART, 2009).

Em virtude do caráter multidimensional da dor, avaliações comportamentais são valiosas e apuram informações não encontradas em testes reflexivos da dor (GREGORY et al., 2013). No entanto, a interferência de fármacos analgésicos deve estar bem descrita para que os efeitos farmacológicos não sejam confundidos com a apresentação da dor. Isso porque, a utilização de fármacos opioides tem sido relacionada a alterações comportamentais em camundongos submetidos a dor aguda (BELKNAP et al., 1998; MIDDAUGH; INGRAM; REYNOLDS, 1983).

Além das alterações comportamentais decorrentes da utilização de opioides, esses fármacos podem afetar o sistema imunológico por diferentes vias, que incluem a ativação via sistema nervoso central (SNC), ativação do sistema nervoso simpático, pela produção de noradrenalina e glicocorticoides, e a ocupação de receptores opioides em células imunológicas (SACERDOTE, 2006). Há indícios de que essa ligação esteja relacionada ao aumento da susceptibilidade dos organismos a agentes infecciosos (MACFARLANE et al., 2000; WANG et al., 2008) bem como à recorrência e progressão tumoral (SNYDER; GREENBERG, 2010). Ainda, a morfina parece favorecer a ocorrência de metástases tumorais por promover a angiogênese tumoral (BIMONTE et al., 2015). Em contraponto, há evidências de que a morfina e metadona podem estar relacionadas a efeitos antineoplásicos, em virtude 
da ativação de p53 pela morfina (TEGEDER et al., 2003) e da ação pró-apoptótica e citotóxica em células tumorais pela metadona (FRIESEN et al., 2011). Ainda, a metadona proporciona bem-estar aos pacientes com dor oncológica refratária a outros opioides (PORTA-SALES et al., 2016).

O tumor ascítico de Ehrlich consiste em um modelo de adenocarcinoma mamário, maligno, com alta proliferação e sem remissão, que acomete espontaneamente camundongos (FASTAIA; DUMONT, 1976; MAYER, 1966) e, que por suas características quantitativas, é utilizado para testar a influência de fármacos no crescimento ou inibição tumoral (HASHEM et al., 2020; KABEER et al., 2019; ROLIM et al., 2017).

Sendo o câncer de mama um problema de saúde mundial e o tratamento da dor com fármacos opioides é indispensável na maioria dos casos. Dessa maneira, vê-se a necessidade da compreensão dos efeitos dos fármacos tanto no comportamento animal, cujos efeitos devem ser conhecidos, bem como, na progressão tumoral frente a utilização da morfina e metadona. 


\section{CARACTERIZAÇÃO DO PROBLEMA}

Segundo o Instituto Nacional de Câncer (INCA), são estimados 625.370 novos casos de câncer no Brasil para o ano de 2020, desses estima-se que 66.280 serão oriundos de câncer de mama e 18.280 serão diagnosticados no estado de São Paulo (INCA, 2019). Esse tipo de câncer consiste no principal tumor diagnosticado em mulheres em todo o mundo e perfaz a principal causa de morte em pacientes acima de 35 anos (FERLAY et al., 2015). O câncer de mama também acomete outros mamíferos. Em cadelas e gatas é considerado o principal tumor diagnosticado, com elevada letalidade devido aos altos graus de malignidade tumoral (SALAS et al., 2015).

Etiologicamente, a dor oncológica advém da invasão tumoral direta nos tecidos, acometimento de vísceras ou outros tecidos moles e/ou metástases (MERCADANTE, 1997). Ainda, pode ser decorrente de diferentes modalidades de terapias, como cirurgias, quimioterapia ou radioterapia (POLOMANO et al., 2001; WOLF et al., 2008), da dor pósoperatória não tratada adequadamente (CHAPMAN; VIERCK, 2017) e pelas doenças concomitantes ao processo tumoral (GAYNOR, 2008). A frequência e intensidade da dor oncológica tende a aumentar com o avançar dos estágios da doença (MANTYH, 2006).

Em humanos a dor de caráter moderado a severo está presente em $28 \%$ dos pacientes recém-diagnosticados, $50 \%$ em pacientes com a doença existente e $80 \%$ em pacientes com tumores avançados e doenças paraneoplásicas (VAN DEN BEUKEN-VAN EVERDINGEN et al., 2016). Há elevada probabilidade de que os níveis de dor em pacientes veterinários sejam semelhantes (LOONEY, 2010), visto que o encaminhamento para atendimento médico ocorre tardiamente, quando o paciente já apresenta sinais de cronicidade da doença, como depressão, anorexia ou metástase (FAN, 2014). Essa demora ou mesmo falhas no reconhecimento ou analgesia inadequada permitem que pacientes sofram em decorrência dessas neoplasias (LOONEY, 2010).

Um dos benefícios no uso experimental de animais baseia-se no desenvolvimento de modelos que representem uma condição humana em termos de comportamento para prever a eficácia de tratamentos (DEUIS; DVORAKOVA; VETTER, 2017). Assim, muitos dos conhecimentos atuais sobre os processos da carcinogênese e eficácia de tratamentos foram fortemente influenciados por modelos experimentais, na maioria das vezes camundongos (FRESE; TUVESON, 2007).

Em 1896 Paul Ehrlich identificou e descreveu uma neoplasia originária de adenocarcinoma mamário em camundongo fêmea e verificou que essa neoplasia poderia ser transplantável. Em 1932, verificou-se a possibilidade de implantação intraperitoneal das 
células neoplásicas que cresciam em suspensão do fluido ascítico. Desde então esse modelo vem sendo amplamente utilizado para testes de medicamentos potencialmente antineoplásicos, devido a uniformidade e padronização do número de células que podem ser inoculadas em camundongos por via subcutânea, para crescimento sólido ou intraperitoneal para crescimento ascítico (FASTAIA; DUMONT, 1976; HARTVEIT, 1964; MAYER, 1966).

Suspeita-se que a inoculação das células na cavidade peritoneal apresente efeito irritante com estímulo à inflamação, aumento da permeabilidade vascular e amplificação da resposta imunológica ocasionada pelo recrutamento de neutrófilos e macrófagos pelas células cancerígenas que liberam citocinas (FASTAIA; DUMONT, 1976). Ainda, o crescimento tumoral promove compressão de vasos sanguíneos e linfáticos com prejuízos ao suprimento de oxigênio e nutrientes, resultando em inflamação e dor, que piora ao longo do tempo (MUNN, 2017).

Para o reconhecimento da dor oncológica alguns fatores e testes comportamentais devem ser aferidos em conjunto e são considerados, como perturbação da marcha ou do peso, força de preensão ou mordida, alteração do comportamento de autolimpeza, posicionamento anormal, levantamento da pata traseira e tremores (comportamentos nocifensivos), hipolocomoção, hipofagia e perda de peso, desatenção a novos estímulos e vocalização ultrassônica (PACHARINSAK; BEITZ, 2008).

Dentre os métodos usuais para avaliação do comportamento de camundongos está o teste do campo aberto ou Open Field. O teste consiste em uma arena que pode ser circular, quadrada ou retangular com paredes que impedem a fuga e parte superior livre que permite a observação ou filmagem. Esse teste foi introduzido por Hall na década de 1930 para ser utilizado em ratos, no entanto, seu uso foi estendido para outras espécies, especialmente camundongos (HALL, 1934; WALSH; CUMMINS, 1976).

Como o teste do campo aberto é baseado no rastreamento do comportamento animal dentro de um novo ambiente, existem vários fatores que podem afetar o resultado final do teste (falso positivo / negativo). Alguns dos possíveis fatores externos incluem parâmetros ambientais do animal, ruído da sala de exame, temperatura, iluminação e linhagem animal. Ainda, seus resultados estão condicionados pela atividade exploratória, medo, ciclo circadiano e doenças (SEIBENHENER; WOOTEN, 2015). Em sua avaliação pode-se observar padrões comportamentais em ambiente novo, como área percorrida, frequência de levantar, tempo gasto na periferia e autolimpeza. Tradicionalmente deve ser realizado entre 2 e 10 minutos, para enfatizar o comportamento exploratório em resposta a novidade (STOJANOVIĆ; RANDJELOVIĆ; RADULOVIĆ, 2017). 
Ressalta-se que o campo aberto consiste em um método útil para a estimativa do comprometimento do movimento do animal, causado pela aplicação de uma substância que afeta a função do SNC e/ou o tônus muscular, bem como alterações comportamentais compatíveis com dor (STOJANOVIĆ; RANDJELOVIĆ; RADULOVIĆ, 2017).

Nos casos de dor oncológica, os opioides são os fármacos de primeira escolha para o tratamento antálgico. São utilizados para o tratamento da dor moderada a severa decorrente da exérese tumoral, da invasão direta dos tecidos ou terapias medicamentosas (LOONEY, 2010). Sua ação se dá por meio da ocupação de receptores opioides $(\mu, \kappa, \delta)$ pré e pós-sinápticos que estão distribuídos em diversos tecidos do organismo, mais concentrados no SNC, no qual modulam a percepção da dor (WALDHOER; BARTLETT; WHISTLER, 2004). A ligação de opioides aos receptores na substância cinzenta periaquedutal está envolvida com a inibição da transmissão GABAérgica, em que o ácido $\gamma$-amino-butírico (GABA) inibe os neurônios inibitórios de dor, que levam a ativação de vias medulares que inibem seletivamente neurônios nociceptivos do corno dorsal da medula espinhal. Ainda, em vias bulboespinhais, ocorre liberação de noradrenalina e serotonina, que atuam na inibição do neurotransmissor pré-sináptico e hiperpolarização pós-sináptica com consequente redução da excitabilidade (YAKSH; YEUNG; RUDY, 1976). Além disso, opioides atuam em fibra C e nos nociceptores da fibra A $\delta$, alterando os estímulos dolorosos (STEIN; LANG, 2009). Em combinação com outros fármacos e de forma dose-dependente, possuem efeitos sedativos a depender da espécie (BASBAUM et al., 2009).

A morfina é o fármaco protótipo dos analgésicos opioides e agonista total dos receptores $\mu$ (GRIMM et al., 2015). Consiste em um opioide potente, recomendado para o tratamento da dor moderada a severa (FALLON et al., 2018). Contudo, a administração de morfina em pacientes oncológicos despertou a suspeita de que além sua ação analgésica pode interferir de maneira significativa no crescimento tumoral (GACH et al., 2011). A morfina aumentou a proliferação de células T98G de glioblastoma humano in vitro (LAZARCZYK; MATYJA; LIPKOWSKI, 2010). Camundongos BALB/c inoculados com carcinoma de Ehrlich na forma sólida apresentaram estimulação da angiogênese tumoral após injeções repetidas de $0,7 \mathrm{mg} / \mathrm{kg}$ de morfina durante sete dias (USTUN et al., 2011). Em camundongos C57BL6 com leucemia EL-4 houve aumento do crescimento tumoral na dose de $10 \mathrm{mg} / \mathrm{kg} / \mathrm{dia}$ administrada durante 10 dias (ISHIKAWA et al., 1993). Verificou-se aumento do número de metástases do carcinoma Walker 256 em ratos sprague dawley após administração única de 5 $\mathrm{mg} / \mathrm{kg}$, por um mecanismo dependente da inibição de células NK, sendo o efeito inibido com administração prévia de naloxona (SIMON; ARBO, 1986). Células tumorais MCF-7 
inoculadas no tecido mamário de ratas apresentaram crescimento associado à angiogênese após administrações seriadas de $0,714 \mathrm{mg} / \mathrm{kg}$ durante 15 dias, por mecanismo dependente da inibição de apoptose celular e progressão do ciclo celular (GUPTA et al., 2002). Administrações prévias de morfina às inoculações tumorais promoveram crescimento tumoral dose-dependente em camundongos C57BL6 com tumor TC-1 (CHENG et al., 2006). Existem indícios de que os mecanismos de metástases estejam associados diretamente a presença de receptores opioides, visto que houve redução de $75 \%$ na incidência de metástases pulmonares do câncer de pulmão de Lewis em camundongos knockout para o receptor $\mu$ opioide, em contrapartida sua presença promoveu aumento de 90\% dos casos (MATHEW et al., 2011).

Outro suposto mecanismo da ação indireta dos opioides no crescimento tumoral relaciona-se com seus efeitos no sistema imunológico (ODUNAYO et al., 2010), em virtude da presença de receptores opioides em várias células imunes (MAKMAN, 1994). Nesse sentido, em condições experimentais, observa-se maior susceptibilidade à infecções e disseminação de tumores com o uso agudo ou crônico de morfina em camundongos (SACERDOTE et al., 2000). O tratamento crônico com morfina em cultura de esplenócitos de rato demonstrou diminuição significativa das citocinas Interleucina-1 (IL-1), Interleucina-2 (IL-2), Fator de Necrose Tumoral- $\alpha$ (TNF- $\alpha$ ) e Interferon- $\gamma$ (IFN- $\gamma$ ) e estimulação de outras citocinas anti-inflamatórias Fator de Crescimento Tumoral- $\beta 1$ (TGF- $\beta 1$ ) e Interleucina-10 (IL-10) (POMORSKA; GACH; JANECKA, 2015). Além disso, a morfina induz apoptose de linfócitos devido ao aumento de expressão de receptores apoptóticos do tipo First Apoptotic Signal (Fas) (YIN et al., 1999).

Contudo, os resultados conflitantes são encontrados após verificação de que altas concentrações de morfina foram capazes de reduzir ou até inibir o crescimento tumoral dos tumores MCF-7 e MDA-MB-231 em camundongos nude (TEGEDER et al., 2003). Em modelos de ratos Fisher com câncer de cólon, a morfina reduziu o crescimento tumoral e a formação de metástases, com redução na carga do tumor hepático com administração de 20 $\mathrm{mg} / \mathrm{kg}$ antes da inoculação tumoral e dois dias após (YEAGER; COLACCHIO, 1991). Em camundongos C57BL6 com câncer de cólon houve inibição da metástase tumoral após administrações seriadas de $10 \mathrm{mg} / \mathrm{kg} /$ dia durante 6 dias iniciando após dois dias da inoculação tumoral com mecanismo de inibição de adesão e invasão de células cancerígenas (inibição da MMP-2) (HARIMAYA et al., 2002). Ainda, existem evidências de que a morfina promova apoptose de células tumorais pela ativação da c-Jun N-terminal kinase (JNK) que leva a produção de espécies reativas de oxigênio e liberação induzida da citocromo c e ativação das caspases e redução da proteína anti-apoptótica Bcl-1 (LIN et al., 2009). 
A metadona é um opioide com potência equivalente à morfina por se ligar aos receptores opioides $\mu$ e atuar como antagonista dos receptores NMDA na medula espinhal. Após a morfina, é o fármaco de eleição para o tratamento da dor oncológica e é empregada quando os outros opioides (especialmente a morfina) perdem a eficácia em decorrência da tolerância (MERCADANTE; BRUERA, 2017a). A metadona é um fármaco que tem demonstrado êxito no tratamento de pacientes humanos com câncer com ênfase em idosos, pois não gera metabólitos ativos e possui baixa depuração renal (MERCADANTE et al., 1999).

Ambos os opioides são utilizados em camundongos com finalidade terapêutica. No entanto, o aumento da atividade locomotora já foi descrito após a administração de morfina (BELKNAP et al., 1998) e metadona (MIDDAUGH; INGRAM; REYNOLDS, 1983) em doses únicas. Os efeitos comportamentais decorrentes da utilização de fármacos são importantes, visto que podem ser confundidos com resultados experimentais.

Há evidências de que a metadona possa ser benéfica no tratamento de pacientes oncológicos no que se refere às ações antitumorais quando combinadas aos quimioterápicos em pacientes com glioblastoma (FRIESEN et al., 2014). Em células leucêmicas tratadas com metadona verificou-se redução de cAMP, ativação de caspases e apoptose das células tumorais, dependente da expressão de receptores opioides, o que culmina na sensibilização das células à ação do quimioterápico doxirrubicina (FRIESEN et al., 2013). Isso merece destaque visto que uma das principais preocupações de oncologistas está na resistência das células neoplásicas a esse medicamento (FRIESEN et al., 2008).

Morfina, buprenorfina, fentanila e metadona já foram testadas em cultura celular de leucemia e glioblastoma, em combinação ou não à quimioterápicos, sendo verificada maior redução do potencial tumoral no grupo metadona (FRIESEN et al., 2011). Ademais, em camundongos C57BL6 tratados com metadona $(12,5 \mathrm{mg} / \mathrm{kg} / \mathrm{dia})$ a ação de neutrófilos, macrófagos e células NK não foi afetada com a administração de metadona (PACIFICI et al., 1994). Em indivíduos dependentes de heroína, os tratamentos com metadona ou buprenorfina restauraram a função imunológica para níveis normais (SACERDOTE et al., 2008).

Em todas as células o mecanismo apoptótico é controlado via proteínas caspases, que são ativadas por clivagem proteolítica em resposta à sinalização celular. A ativação das caspases é rigorosamente controlada no meio intracelular pelas proteínas Bcl-2, ativadas pelo citocromo $\mathrm{C}$ que promove ativação dos mecanismos de apoptose. Esse processo é de extrema importância nos organismos, visto que está relacionado ao funcionamento adequado do sistema imunológico, desenvolvimento embrionário, morte celular de células alteradas dentre 
outros processos e pode ser utilizada como alvo terapêutico (ELMORE, 2007; HENGARTNER, 2000; MEIER; FINCH; EVAN, 2000).

A multiplicação das células tumorais se orienta via princípios de duplicação e divisão do ciclo celular, comum a todas as células eucariontes. Durante os processos oncogênicos a maior regulação ocorre na fase G1. Nessa fase as células saem do estado de repouso e tornamse continuamente ativas, com crescimento contínuo. Após a fase G1 as células entram na fase S que corresponde à fase de replicação do DNA. A conclusão da síntese de DNA é seguida pela fase G2 em que ocorre o crescimento e as células preparam-se para a mitose. No ciclo celular de células cancerígenas o controle antiproliferativo não ocorre adequadamente e as células permanecem em ciclo contínuo (SHERR, 1996).

Para verificar o estágio do ciclo celular em que as células se encontram, é avaliado o conteúdo de DNA celular. Células em estágio G1 são diploides, isto é, contém duas cópias de cada cromossomo. Durante a fase S, a replicação aumenta e o conteúdo passa de 2n para 4n. Essa distinção é analisada por citometria de fluxo, em que o conteúdo de DNA nuclear é medido quantitativamente. Inicialmente, adiciona-se um corante fluorescente à suspensão de células que se liga ao DNA; em seguida o material corado é mensurado no citômetro e os sinais eletrônicos emitidos de acordo com a intensidade geram um histograma em que as fases em que as células se encontram podem ser identificadas (NUNEZ, 2001).

Sendo que camundongos são utilizados frequentemente para a pesquisa oncológica, a identificação e o tratamento adequado da dor nesses animais são essenciais para a condução de um estudo ético colaborando para melhorar a qualidade de vida dos modelos experimentais (TURNER; PANG; LOFGREN, 2019). 


\section{OBJETIVOS}

\subsection{OBJETIVO GERAL}

Determinar a influência da morfina ou metadona na analgesia, efeitos comportamentais e crescimento do tumor ascítico de Ehrlich (TAE) em camundongos fêmeas $\mathrm{BALB} / \mathrm{cJ}$.

\subsection{OBJETIVOS ESPECÍFICOS}

- Verificar o período antinociceptivo promovido por três diferentes doses de morfina ou metadona em camundongos BALB/cJ por meio de testes comportamentais de campo aberto e pinçamento de cauda.

- Determinar se a morfina e a metadona em diferentes doses promovem antinocicepção cumulativa após administrações seriadas em camundongos BALB/cJ por meio da realização de testes comportamentais, após administrações seriadas, durante 3 dias.

- Avaliar alterações comportamentais decorrentes da administração de morfina ou metadona e comparar entre as diferentes doses administradas por meio da avaliação da distância percorrida, velocidade média, frequência de levantar e autolimpeza em camundongos $\mathrm{BALB} / \mathrm{cJ}$.

- Avaliar as diferenças no crescimento do TAE após sete dias de administração de três doses de morfina ou metadona, por meio de aferição do volume e contagem de células tumorais em fêmeas de camundongos BALB/cJ;

- Aferir se a morfina e a metadona interferem no ciclo celular das células tumorais por meio de citometria de fluxo.

\section{HIPÓTESES}

- A morfina e a metadona promoverão analgesia de maneira dose-dependente em camundongos BALB/cJ.

- A morfina e a metadona quando administradas em pacientes oncológicos, irão promover excitação e alterações comportamentais leves em camundongos BALB/cJ.

- A morfina, mas não a metadona irá promover aumento tumoral de maneira dose-dependente em camundongos tratados de maneira prolongada. 


\title{
5 ESTUDO 1 - THREE-DAY CONSECUTIVE ADMINISTRATION OF MORPHINE OR METHADONE PROMOTES ANTINOCICEPTION AND INCREASES BEHAVIOURAL ACTIVITY IN MICE WITH EHRLICH CARCINOMA
}

Enviado para publicação em 27/04/2020 para a revista "Journal of the American Association for Laboratory

Animal Science”, sob o protocolo JAALAS-20-000053.

\begin{abstract}
The study assessed the exploratory and nociceptive behavioural responses in BALB/c mice with Ehrlich's ascitic carcinoma following prolonged treatment with morphine or methadone. Fifty-three female mice, $60 \pm 10$ days old, were used. Seven days after intraperitoneal tumour inoculation $\left(2 \times 10^{6}\right.$ cells $)$, the animals were randomised into seven groups: morphine 5 $\mathrm{mg} / \mathrm{kg}\left(\mathrm{MO}_{5}\right)$, morphine $7.5 \mathrm{mg} / \mathrm{kg}\left(\mathrm{MO}_{7.5}\right)$, morphine $10 \mathrm{mg} / \mathrm{kg}\left(\mathrm{MO}_{10}\right)$, methadone 2.85 $\mathrm{mg} / \mathrm{kg}\left(\mathrm{ME}_{2.85}\right)$, methadone $4.3 \mathrm{mg} / \mathrm{kg}\left(\mathrm{ME}_{4.3}\right)$, methadone $5.7 \mathrm{mg} / \mathrm{kg}\left(\mathrm{ME}_{5.7}\right)$, and $0.9 \% \mathrm{NaCl}$ (Sal) $(\mathrm{n}=7)$. Treatments were administered subcutaneously, every $6 \mathrm{~h}$, for 3 days. The animals were evaluated for general activity and nociception using the open field and tail clip tests, respectively. These tests were performed before tumour inoculation (day 0); at 40, 90, 150, 240, and $360 \mathrm{~min}$ following treatment initiation (day 7); and at 40, 150, and $360 \mathrm{~min}$ after days 8 and 9 post-inoculation. All evaluated doses promoted a significant dosedependent increase in the total distance travelled and the average speed, markedly pronounced on days 8 and 9 than on day 7. The frequencies of rearing and self-grooming decreased significantly after morphine or methadone administration. A single morphine administration $(10 \mathrm{mg} / \mathrm{kg})$ promoted antinociception for $150 \mathrm{~min}$. Similarly, repeated administrations of 7.5 $\mathrm{mg} / \mathrm{kg}$ of morphine or 4.3 and $5.7 \mathrm{mg} / \mathrm{kg}$ of methadone demonstrated a nociceptive effect for up to $150 \mathrm{~min}$. Notably, $10 \mathrm{mg} / \mathrm{kg}$ of morphine or $5.7 \mathrm{mg} / \mathrm{kg}$ of methadone were considered the most suitable, as both showed an antinociceptive effect for up to $150 \mathrm{~min}$ in the Ehrlich carcinoma model. All test doses promoted increased locomotion and reduced exploratory behaviour, which was markedly evident during the treatment period.
\end{abstract}

Key words: behavioural test; opioid; oncological pain.

\subsection{INTRODUCTION}

Breast neoplasms are among the leading causes of cancer deaths in women over the age of 35 worldwide. ${ }^{10,19}$ In these cases, the treatment or the direct invasion of the tumour into the tissues can cause painful stimuli, of moderate to severe intensity. ${ }^{23,41}$ Ehrlich carcinoma is an experimental model of a mouse tumour derived from mammary adenocarcinoma, which progresses with rapid proliferation. ${ }^{6}$ When the tumour develops in the ascitic form, the inflammatory response is triggered by the presence of tumour cells in the peritoneum, with increased vascular permeability and impaired lymphatic drainage. This process of fluid accumulation increases abdominal pressure, and consequently pain. ${ }^{27}$

In cancer patients, the importance of adequate pain control is concerned with ensuring patient survival as well as improving the quality of life. ${ }^{21,41}$ In this context, morphine and 
methadone have so far been considered excellent choices for antalgic cancer therapy. ${ }^{9,24,40}$ The growing concerns with pain management, especially in experimental models, have made it essential to characterise behaviours associated with the use of drugs as some of these behaviours are also associated with pain responses and may eventually interfere in the behavioural analysis and, consequently, in the treatment itself. ${ }^{8}$

As pain is a multidimensional experience, the behavioural test results determined in animals translate information complementary to reflex or nociception tests, ${ }^{8}$ and are fundamental for neurobehavioral studies in rodents. ${ }^{38}$ Accordingly, the open field is a widely used test for the analysis of exploratory behaviours. Analyses such as distance travelled, selfgrooming, and rearing frequency can provide information regarding the general behaviour of the animal, ${ }^{36}$ frequently associated with anxiety and stress, ${ }^{32}$ and with the emotional behaviour of mice. ${ }^{36}$ Reportedly, $\mu$-opioid receptor agonists, administered as a single dose in animals subjected to acute pain stimuli, have demonstrated behavioural changes including hyperlocomotion as well as changes in the frequency of self-grooming and rearing. ${ }^{15,30,33}$

Hence, in the present study, we aimed to assess the exploratory and nociceptive behavioural reactions of $\mathrm{BALB} / \mathrm{c}$ mice in a paradigm of compressive inflammatory pain, resulting from an experimental model of Ehrlich's ascitic carcinoma, and treated with morphine or methadone. We hypothesised that morphine and methadone would promote analgesia, increase general activity, and reduce the frequency of self-grooming in a dosedependent manner.

\subsection{MATERIAL AND METHODS}

\subsubsection{Animals}

All the procedures were conducted in accordance with the Ethics Committee of the Faculty of Animal Science and Food Engineering, University of São Paulo, Brazil (3836220518). In this study, we used 53 female BALB/cJ mice, $60 \pm 10$ days old, and weighing $25 \pm 5 \mathrm{~g}$, from the animal house of the Department of Pathology, School of Veterinary Medicine and Animal Science, University of São Paulo. The animals were housed in a specific vivarium, with conventional status randomly arranged in cages $(37 \times 22 \times 15 \mathrm{~cm})$ housing three to four animals, under conditions of controlled temperature $\left(22-23^{\circ} \mathrm{C}\right)$, with a 12-h light/dark cycle with lights on at 6:30 a.m., and water and food available ad libitum. The 
animals were allowed a 10-day minimum acclimation period before the start of the experiment in Veterinary Toxicology Research Center (CEPTOX).

\subsubsection{Drugs}

As drug treatment, morphine sulphate (Dimorf®, Cristalia, São Paulo, Brazil) and methadone hydrochloride (Mytedon®, Cristalia, São Paulo, Brazil) were used.

\subsubsection{Treatment protocol}

Initially, a single mouse was inoculated with the Ehrlich carcinoma cells, which were maintained in a cell bank at $-80^{\circ} \mathrm{C}$. Fourteen days after inoculation, the donor mouse was euthanised in a $\mathrm{CO}_{2}$ chamber, followed by cervical dislocation. The peritoneal fluid was collected $(0.1 \mathrm{~mL})$ and used to inoculate a second cell-carrier/donor mouse for the maintenance of the tumour cells in vivo. ${ }^{12}$ This procedure was repeated three times until the cell viability was greater than $95 \%$, indicating adequate experimental conditions.

In the experimental groups, the animals were intraperitoneally administered $2 \times 10^{6}$ Ehrlich tumour cells from the donor mouse. Seven days after tumour inoculation, the animals were randomised into seven groups: morphine $5 \mathrm{mg} / \mathrm{kg}\left(\mathrm{MO}_{5}\right)$, morphine $7.5 \mathrm{mg} / \mathrm{kg}\left(\mathrm{MO}_{7.5}\right)$, morphine $10 \mathrm{mg} / \mathrm{kg}\left(\mathrm{MO}_{10}\right)$, methadone $2.85 \mathrm{mg} / \mathrm{kg}\left(\mathrm{ME}_{2.85}\right)$, methadone $4.3 \mathrm{mg} / \mathrm{kg}\left(\mathrm{ME}_{4.3}\right)$, methadone $5.7 \mathrm{mg} / \mathrm{kg}\left(\mathrm{ME}_{5.7}\right)$, and $0.9 \%$ saline $(\mathrm{Sal})(\mathrm{n}=7)$. The drugs were administered subcutaneously every $6 \mathrm{~h}$, for 3 days. In this study, the morphine doses were based on previous literature, ${ }^{6,17}$ while the methadone doses were selected according to its equipotency of 1,75 times to morphine. ${ }^{24}$ The final volume of each treatment was standardised in $0.3 \mathrm{~mL}$ of solution, adjusted with $0.9 \% \mathrm{NaCl}$.

\subsubsection{Behavioural tests}

The behavioural influence of opioids was evaluated by assessing the total distance travelled $(\mathrm{cm} / 5 \mathrm{~min})$, the average speed $(\mathrm{cm} / \mathrm{s})$, and the rearing and self-grooming frequencies of the animals in the open field test. The mice were individually placed in the centre of the circular arena (40 cm in diameter and $50 \mathrm{~cm}$ in height) and recorded for $5 \mathrm{~min}$ in the absence of humans, using a video camera positioned vertically above the open field. Between individuals tests conducted, the arena was sanitised with a 5\% alcohol solution. The animals were tested at baseline, defined as the moment before tumour inoculation (day 0 ), 
subsequently at 40, 90, 150, 240 and 360 min after treatment initiation (day 7), and at 40, 150 and 360 min after days 8 and 9 post-inoculation.

The total distance travelled and the average speed were evaluated from the videorecorded data obtained in the open field using the Ethovision software (EthoVission XT, Noldus, Version 7.1). The rearing frequency was determined as the number of times the animal stood on its hind limbs. The frequency of self-grooming was determined based on the number of times the animal cleaned its limbs and body during a 5 min period. Both these measures were assessed manually during the retrospective evaluation of the recorded videos.

\subsubsection{Nociception test}

After assessing the animals in the open field, nociception was evaluated within the arena, by clipping the first level on a Halstead haemostatic forceps, approximately $1.5 \mathrm{~cm}$ caudal to the base of the tail. The response to mechanical pressure was scored as 0 - no answer, 1 - looking at the tail, 2 - taking a step, 3 - running, and 4 - leaping and biting.

\subsubsection{Statistical analysis}

The data were analysed using GraphPad Prism version 7.0 (GraphPad Software, Inc., La Jolla, CA, USA). Normality was verified by the Shapiro-Wilk test. The total distance travelled and the average speed were analysed by analysis of variance (ANOVA), followed by Dunnet's post-test for group comparisons, at each time point, compared with the Saline group, and for intra-group comparisons against the respective baseline. The abdominal circumference, rearing frequency, frequency of self-grooming, and response to the tail clip test were analysed using the Kruskal-Wallis test and Dunn's post-test for comparison between groups, at each time point, compared with the Saline group; the Friedman test and postDunn's test were used for intra-group comparisons against the respective baseline. The correlations between each of the parameters (distance travelled, average speed, rearing frequency, and self-grooming) and opioid doses were assessed using Pearson's correlation. The level of significance was set as $5 \%(\mathrm{p}<0.05)$.

\subsection{RESULTS}

After tumour inoculation, the animals were observed daily to assess daily water and food consumption, and the overall condition. All mice developed Ehrlich's ascitic carcinoma during the seven days of incubation, and none died before the end of the experimental period. 
In general, an increase in the intra-abdominal volume was observed from day 6 when compared to day 0 ( $\mathrm{p}<0.04)$, confirmed after euthanasia with volume collection. Reduced locomotor activity and grooming were observed from day 7, and these parameters worsened as the experimental period progressed. Feed intake was significantly lower on days 8 and 9 (p $<0.0001)$.

\subsubsection{Distance travelled}

In the Saline group, a significant decrease was observed in the total distance travelled at all evaluated time points than at the baseline $(\mathrm{p}<0.008)$. A strong correlation was observed amongst the morphine doses evaluated and the distance travelled $(\mathrm{r}=0.86)$. In the $\mathrm{MO}_{5}$ group, an increase in the distance travelled was observed on day 8 at $40 \mathrm{~min}$ when compared to the baseline ( $\mathrm{p}=0.0296$ ); a decrease was also observed on days 8 and 9 at $360 \mathrm{~min}(\mathrm{p}$ $<0.0032$ ). In the $\mathrm{MO}_{7.5}$ group, the distance travelled decreased to the baseline on days 8 and 9 at $360 \mathrm{~min}$ ( $\mathrm{p}<0.0423$ ). Compared to that in the Saline group, an increase was observed in the distance travelled in the $\mathrm{MO}_{5}$ and $\mathrm{MO}_{7.5}$ animals at $40 \min (\mathrm{p}=0.0256)$ and $90(\mathrm{p}=0.0062)$ on day 7 , and at 40 min on days $8(\mathrm{p}=0.0002)$ and $9(\mathrm{p}=0.0014)$. In the $\mathrm{MO}_{10}$ group, the distance travelled was increased at $40(\mathrm{p}=0.0001)$ and $150(\mathrm{p}<0.0058) \mathrm{min}$ on days 7 and 8 , but only at $40 \mathrm{~min}$ on day $9(\mathrm{p}=0.0014)$ (Figure 1$)$.

Regarding methadone treatments, a weak correlation was observed between the tested doses and the distance travelled $(r=0.59)$. In the $\mathrm{ME}_{2.85}$ group, the animals showed a decrease in the distance travelled at $360 \mathrm{~min}$ on day 8 when compared with baseline $(\mathrm{p}$ $<0.0333$ ). In the case of the $\mathrm{ME}_{4.3}$ group, a decrease in the distance travelled was observed when compared with baseline at $150 \mathrm{~min}$ on day $8(\mathrm{p}=0.0075)$ and at $360 \mathrm{~min}$ on days 8 and 9 ( $\mathrm{p}<0.0157)$. Compared with that in the Saline group, an increase in the distance travelled in $\mathrm{ME}_{2.85}$ and $\mathrm{ME}_{4.3}$ groups was observed at 40 min on days 7 (p <0.0021), 8 (p <0.0037), and 9 ( $\mathrm{p}<0.0008)$. The highest dose of methadone $\left(\mathrm{ME}_{5.7}\right)$ promoted an increase in the distance travelled until 90 min on day 7 ( $\mathrm{p}<0.0093)$, and at 40 min on days 8 (p<0.0001) and 9 (p $<0.0001$ ) (Figure 1). 
Figure 1. Locomotor activity (distance covered and average speed) over time after repeated administration (every 6 hours) of morphine or methadone in different dosages, for 3 days (day 7, 8 and 9 after tumor inoculation). Values are expressed as mean \pm standard deviation (n $=7$ ). $p$ $<0.05$ compared to the Control group (*) and to baseline values $(\S)$ through the one-way ANOVA test and Dunnet test.
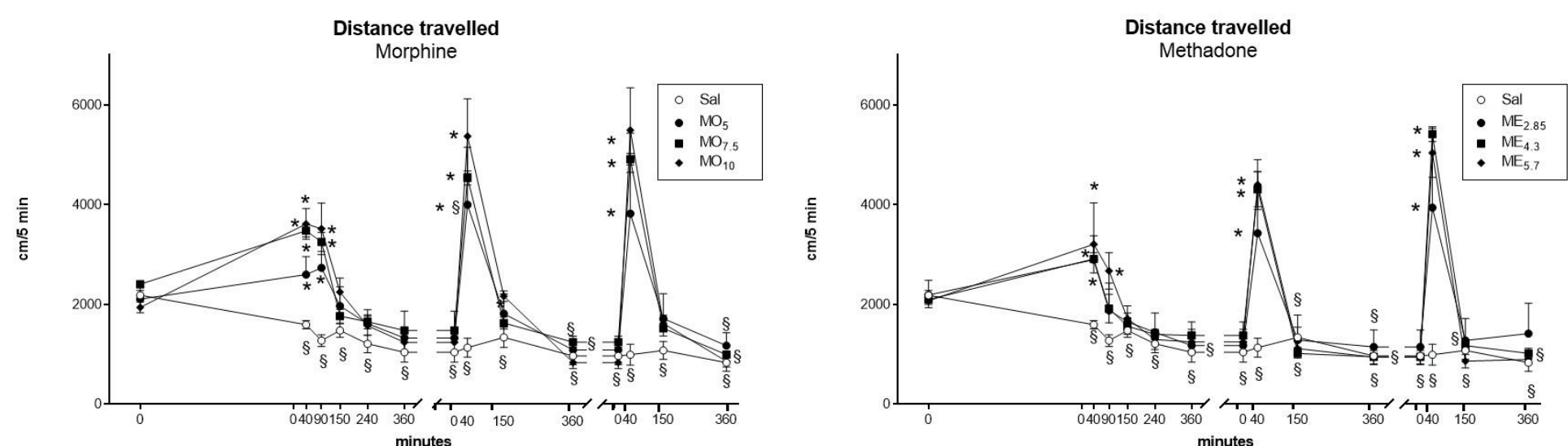

Day 0

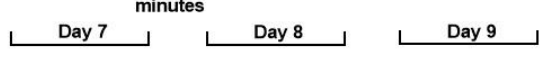

Day 0

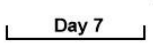

minutes
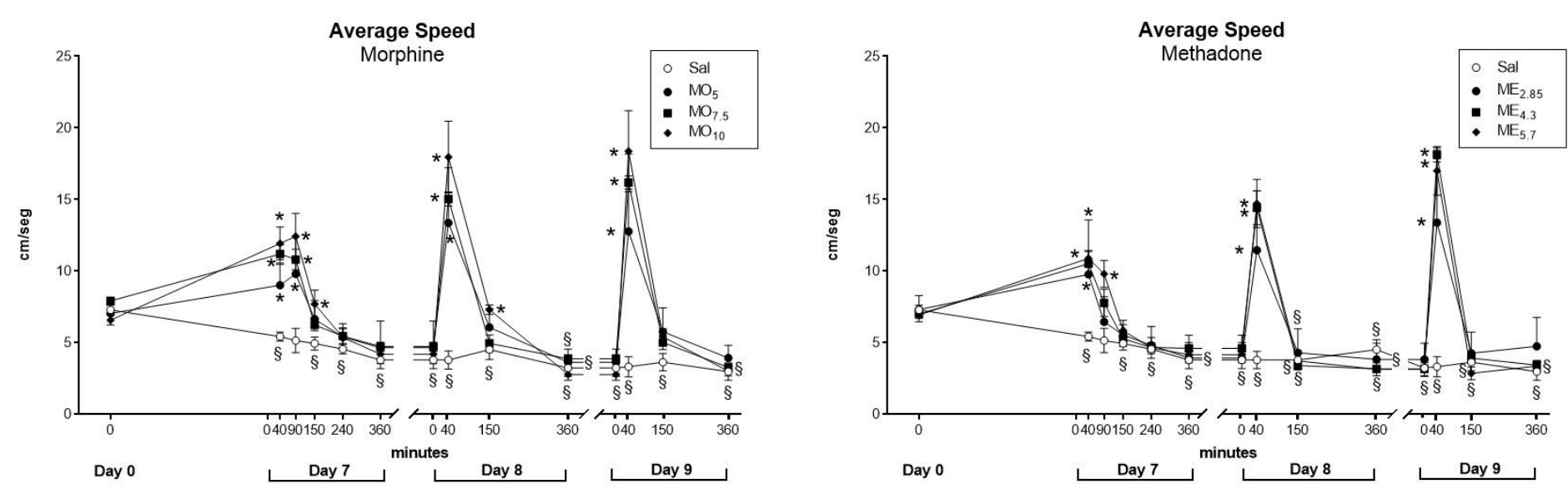

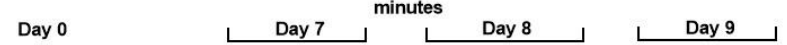

Day 0

Source: prepared by the author 


\subsubsection{Average speed}

In the Saline group, the average speed was reduced when compared to the baseline, except at 90 min of day 7. A strong correlation was observed amongst the morphine doses evaluated and the average speed $(\mathrm{r}=0.81)$. Additionally, the average speed was reduced at 360 min on day 8 in the $\mathrm{MO}_{5}$ and $\mathrm{MO}_{7.5}$ animals ( $\mathrm{p}<0.0423$ ), and at 360 min on day 9 in the $\mathrm{MO}_{7.5}$ group $(\mathrm{p}=0.0122)$. Compared with the Saline group, animals in $\mathrm{MO}_{5}$ and $\mathrm{MO}_{7.5}$ demonstrated a significant increase in the average speed between $40(\mathrm{p}<0.00216)$ and 90 (p < 0.0074 ) $\min$ on day 7 , but only at $40 \mathrm{~min}$ on days 8 and 9 . An increase in the average speed was observed in the $\mathrm{MO}_{10}$ group, between 40 and 150 min on days 7 and 8, and only at 40 min on day 9 (Figure 1).

A weak correlation was observed in the methadone treatments between the doses evaluated and average speed $(\mathrm{r}=0.63)$. In the $\mathrm{ME}_{2.85}$ group, the average speed decreased at $360 \mathrm{~min}$ on days 7 and $8(\mathrm{p}<0.0475)$ and at $150 \mathrm{~min}$ on day $8(\mathrm{p}=0.0054)$ when compared with the baseline. Furthermore, this parameter demonstrated reduced values in the $\mathrm{ME}_{4.3}$ group between 150 and $360 \mathrm{~min}$ on day $8(\mathrm{p}=0.0157)$ and only at $360 \mathrm{~min}$ on day $9(\mathrm{p}<0.0316)$. The highest methadone dose $\left(\mathrm{ME}_{5.7}\right)$ increased the average speed at $150 \mathrm{~min}$ on day $9(\mathrm{p}=$ 0.0333) (Figure 1). Compared with the Saline group, the $\mathrm{ME}_{2.85}$ and $\mathrm{ME}_{4.3}$ animals showed a significant increase in the average speed at $40 \mathrm{~min}(\mathrm{p}<0.0035)$ on all test days. In the $\mathrm{ME}_{5.7}$ group, an increased average speed was observed between $40(\mathrm{p}=0.0002)$ and $90(\mathrm{p}=0.0074)$ $\min$ on day 7 and only at $40 \min (\mathrm{p}=0.0001)$ on days 8 and 9 (Figure 1$)$.

\subsubsection{Rearing frequency}

Regarding the rearing frequency, the Saline group animals demonstrated a significant decrease at $360 \mathrm{~min}$ on day 7 , and at every time point evaluated on day 9 (p <0.02). A strong negative correlation was observed between the morphine doses tested and the rearing frequency $(r=-0.8)$. Additionally, the rearing frequency was significantly reduced in the $\mathrm{MO}_{5}$ animals between 40 and $90 \mathrm{~min}$ on day 7 ( p <0.0001) and between 40 and 150 min on days 8 and 9 ( $\mathrm{p}$ <0.0204). In the $\mathrm{MO}_{7.5}$ and $\mathrm{MO}_{10}$ groups, the rearing frequency was reduced at all time points evaluated ( $\mathrm{p}<0.0231$ ). Compared with the Saline group, the $\mathrm{MO}_{5}$ animals reared less on day 7 , between 40 and $90 \mathrm{~min}(\mathrm{p}=0.0001)$. On day 8 , a significant decrease was observed from $40(\mathrm{p}<0.0001)$ to $150 \mathrm{~min}(\mathrm{p}=0.0165)$; on day 9 , the rearing frequency was reduced only at $40 \mathrm{~min}(\mathrm{p}=0.0001)$. In the $\mathrm{MO}_{7.5}$ and $\mathrm{MO}_{10}$ groups, the rearing frequency 
was reduced from 40 to $150 \mathrm{~min}$ on day 7 and 8 (p <0.0103) and at 40 min on day 9 ( $\mathrm{p}=$ 0.0001) (Figure 2). 
Figure 2. Exploratory behavior (rearing frequency and grooming frequency) over time after repeated administration (every 6 hours) of morphine or methadone in different dosages, for 3 days (day 7, 8 and 9 after tumor inoculation). Values are expressed as median (interquartile range) (n $=$ 7). * $p<0.05$ compared to the Control group through the Kruskal-Wallis and Dunn test, and to baseline values $(\S)$ through the Friedman and Dunn test.
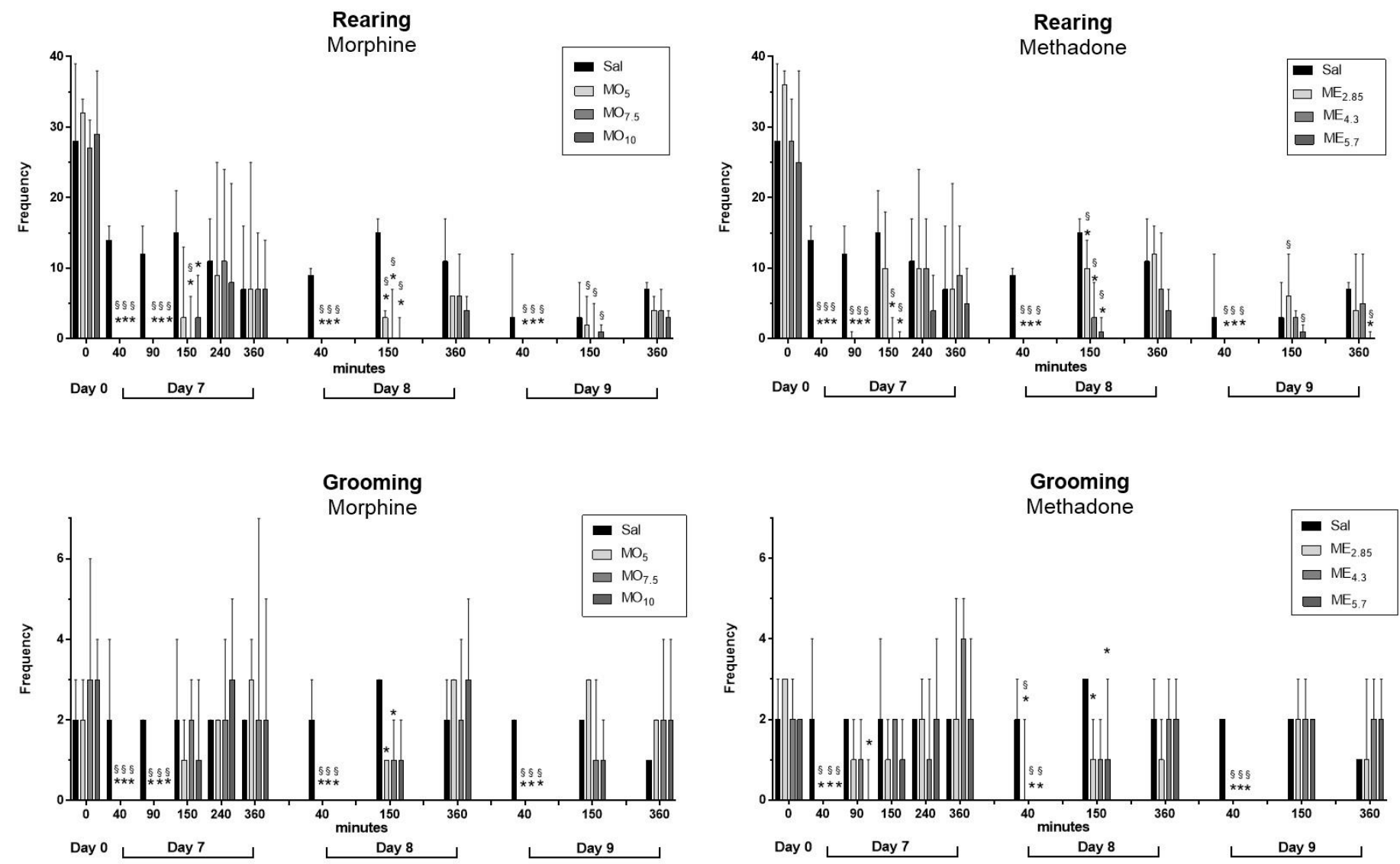

Source: prepared by the author 


\subsubsection{Frequency of self-grooming}

No significant difference was observed in the Saline group animals regarding the frequency of self-grooming when compared with baseline. A negative correlation was observed between grooming frequency and the morphine doses tested $(\mathrm{r}=-0.8)$. In the $\mathrm{MO}_{5}$ group, decreased grooming was observed at 40 min on days 7,8 , and 9 (p <0.0231) when compared with baseline. In the $\mathrm{MO}_{7.5}$ and $\mathrm{MO}_{10}$ groups, a difference was detected at 40 and $90 \min (\mathrm{p}<0.0295)$ on day 7 and at 40 min on days 8 and 9 ( $\mathrm{p}<0.0258)$. In the $\mathrm{MO}_{5}$ and $\mathrm{MO}_{7.5}$ groups, grooming was reduced between 40 (p <0.0001) and $90 \mathrm{~min}(\mathrm{p}<0.0117)$ on day 7 , between $40(\mathrm{p}<0.0001)$ and $150 \mathrm{~min}(\mathrm{p}=0.0377)$ on day 8 , and only at $40 \mathrm{~min}(\mathrm{p}=$ 0.0006) on day 9. In $\mathrm{MO}_{10}$ animals, reduced grooming was observed between 40 ( $\left.\mathrm{p}<0.0001\right)$ and $90 \min (\mathrm{p}=0.0013)$ on day 7 and only at $40 \mathrm{~min}(\mathrm{p}<0.0001)$ on days 8 and 9 (Figure 2$)$.

In mice treated with methadone, a weak correlation was observed with increased dosing (-0.4). The frequency of grooming was reduced when compared with baseline at 40 min on all test days ( $\mathrm{p}<0.0333$ ) (Figure 2). In the $\mathrm{ME}_{2.85}$ group, grooming decreased at 40 $\min (\mathrm{p}<0.0001)$ on day 7 , between $40(\mathrm{p}=0.0002)$ and $150 \mathrm{~min}(\mathrm{p}=0.0299)$ on day 8 , and only at $40 \mathrm{~min}(\mathrm{p}<0.0001)$ on day 9 . In $\mathrm{ME}_{4.3}$ animals, significant differences were observed only at $40 \mathrm{~min}(\mathrm{p}<0.0001)$ on all test days. In the $\mathrm{ME}_{5.7}$ group, the frequency of grooming significantly differed between $40(\mathrm{p}<0.0001)$ and $90 \mathrm{~min}(\mathrm{p}=0.0225)$ on day 7 , at $150 \mathrm{~min}(\mathrm{p}$ $<0.0389$ ) on day 8 , and at $40 \mathrm{~min}(\mathrm{p}<0.0001)$ on day 9 (Figure 2 ).

\subsubsection{Tail clip test}

In the Saline group animals, no difference was observed in the response to the tail clip test. A strong positive correlation $(r=0.8)$ was observed between antinociception and the dose of both opioids. All morphine doses evaluated, as well as the highest methadone dose $(5.7 \mathrm{mg} / \mathrm{kg})$, reduced the response to mechanical stimuli between 40 and $90 \mathrm{~min}$ on day 7 (p $<0.0107$ ), and at $40 \mathrm{~min}$ on days 8 and 9 ( $\mathrm{p}<0.0158$ ). In the $\mathrm{ME}_{2.85}$ and $\mathrm{ME}_{4.3}$ group, a reduced response was observed only at $40 \mathrm{~min}$ on all test days $(\mathrm{p}<0.0034)$.

Compared with the Saline group, the response to tail clipping significantly reduced in the $\mathrm{MO}_{5}$ animals between $40(\mathrm{p}<0.0001)$ and $90 \mathrm{~min}(\mathrm{p}=0.0188)$ on day 7 , and only at 40 $\min (\mathrm{p}<0.0025)$ on days 8 and 9 . In the $\mathrm{MO}_{7.5}$ group, a difference was observed between 40 (p <0.0001) and $90 \mathrm{~min}(\mathrm{p}<0.0024)$ on day 7 , at $40 \mathrm{~min}(\mathrm{p}<0.0001)$ on day 8 , and between 
$40(\mathrm{p}<0.0001)$ and $150 \mathrm{~min}(\mathrm{p}=0.0079)$ on day 9. In $\mathrm{MO}_{10}$ animals, a reduced response was observed between $40(\mathrm{p}<0.0002)$ and $150 \mathrm{~min}$ ( $\mathrm{p}<0.0295)$ on all test days (Figure 3 ).

In the methadone treated mice, the response to tail clipping decreased in the $\mathrm{ME}_{2.85}$ group only at $40 \mathrm{~min}$ ( $\mathrm{p}<0.0001)$ on all test days. In $\mathrm{ME}_{4.3}$ animals, a reduced response was observed only at $40 \mathrm{~min}$ ( $\mathrm{p}<0.0001)$ on days 7 and 8 , and between 40 (p <0.0001) and 150 $\min (\mathrm{p}=0.0355)$ on day 9 . In the $\mathrm{ME}_{5.7}$ group, a significant decrease was observed between $40(\mathrm{p}<0.0001)$ and $90 \min (\mathrm{p}=0.0002)$ on day 7 , and between $40(\mathrm{p}<0.0001)$ and $150 \mathrm{~min}(\mathrm{p}$ $<0.0366$ ) on days 8 and 9 (Figure 3). 
Figure 5.3. Response to tail clipping over time after repeated administration (every 6 hours) of morphine or methadone in different dosages, for 3 days (day 7, 8 and 9 after tumor inoculation). Values are expressed as median (interquartile range) $(\mathrm{n}=7)$. $* p<0.05$ compared to the Control group through the Kruskal-Wallis and Dunn test and to baseline values $(\S)$ through the Friedman and Dunn test.
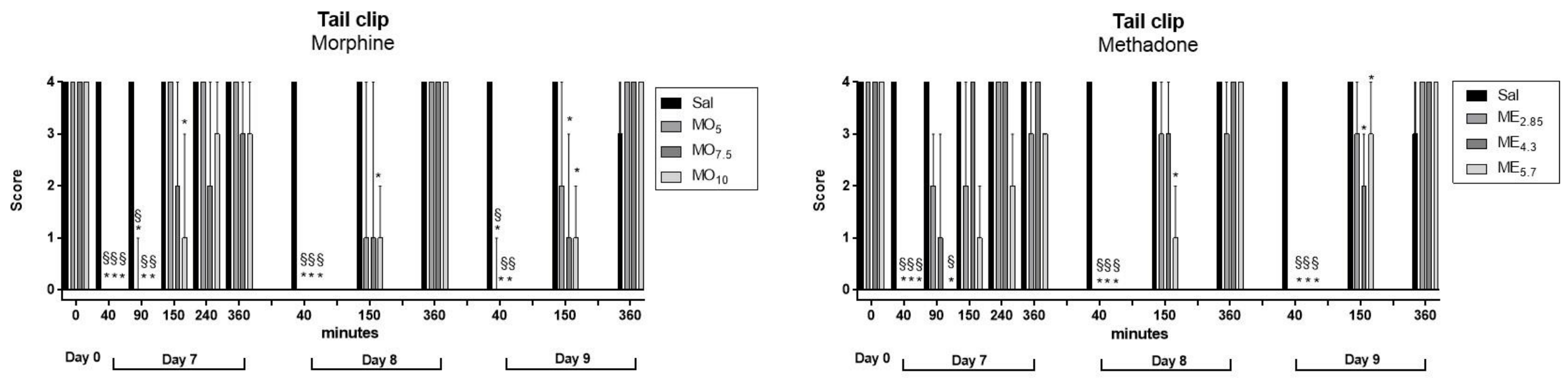

Source: prepared by the author 


\subsection{DISCUSSION}

In this study, all animals showed physical and behavioural changes secondary to tumour development. Ehrlich's tumour model is considered highly aggressive, with inflammatory and compressive characteristics. ${ }^{11}$ The animals displayed reduced activity within the cage, grooming from the $7^{\text {th }}$ day of evaluation, and an increase in abdominal circumference, significant from the $6^{\text {th }}$ day of evaluation. Sadly, the food intake was significantly decreased on days 8 and 9 but was unquantifiable. Although the exact onset of pain remains undefined, the signs observed are considered representative of the clinical conditions of oncological disease. ${ }^{28}$

Following the morphine administration, locomotor activity increased in a dosedependent manner, even at doses lower than those studied with a similar increase in locomotor activity. ${ }^{20,30,39}$ Although the general activity increased significantly after methadone administration, as previously verified, ${ }^{25}$ the results were not dose-dependent. This probably occurred due to insufficient differentiation among doses, which were determined as equipotent to the morphine doses; the same effect could have occurred if higher methadone doses were tested.

Notably, in the case of prolonged treatments, the intensity of locomotor activity increased on days 8 and 9 when compared to day 7 , for both the intermediate and the highest morphine and methadone doses. This has not been documented in previous studies, with animal activity evaluated after a single drug administration., ${ }^{4,25,30}$. Drug administration for 7 days have been investigated, but the increase in the locomotor activity over the initial days was not compared. ${ }^{39}$ It is postulated that the intensification in locomotor activity after repeated drug administration is related either to adequate pain control or to the excitation promoted by the opioids, secondary to the dopamine release in the nucleus accumbens. ${ }^{7,18,20}$; additionally, it may be related to a possible cumulative effect. To clarify this effect, elevated doses or longer duration of treatment would be necessary.

A high negative correlation was observed between the total distance travelled/average speed and the rearing frequency in morphine treated animals, corroborating another study. ${ }^{30}$ As the rearing frequency is triggered and modulated by the hippocampus, it is enhanced in situations of uncertainty or following the administration of psychoactive agents containing caffeine, ${ }^{26}$ as well as ketamine. ${ }^{22} \mathrm{~A}$ reduced rearing frequency is observed when the environment is deemed 
dangerous/unfamiliar, thus inhibiting the exploratory drive ${ }^{14}$ in situations of stress, anxiety, ${ }^{37}$, ataxia, or owing to an increase in horizontal locomotor activity. ${ }^{13}$

Furthermore, the frequency of self-grooming diminished after the administration of both morphine and methadone. Grooming behaviour is considered innate in rodents and is associated with hygiene maintenance, thermoregulation, social communication, and excitement. ${ }^{35}$ It remains one of the primary behaviours assessed in rodents and has a distinct sequence, with cephalocaudal progression. ${ }^{34}$ Notably, drugs that alter the dopamine release, ${ }^{1}$ as in the case of morphine, or with GABAergic inhibitory action ${ }^{3}$ and NMDA antagonism, as in the case of methadone, can modify the frequency and the sequence of the self-grooming process in rodents. ${ }^{2}$ Furthermore, the increase, as well as the inhibition of this behaviour, are associated with the clinical manifestation of oncologic pain. ${ }^{28}$ Although no test is able to directly measure pain in animals, the observation of changes in behavioral patterns may indicated in the reduction of ambulation, agitation, and alteration of rearing and of the sequence and frequency of grooming. ${ }^{8}$

In the case of morphine, the tail clip test demonstrated an antinociceptive effect lasting up to $90 \mathrm{~min}$ following the administration of 5 and $7.5 \mathrm{mg} / \mathrm{kg}$ morphine, and up to $150 \mathrm{~min}$ with the $10 \mathrm{mg} / \mathrm{kg}$ dose. These results differ from those reported previously, 5 in which $10 \mathrm{mg} / \mathrm{kg}$ morphine promoted antinociception for up to $90 \mathrm{~min}$ in C57BL/6 mice during the hot plate test. We suggest that the difference in the strain or pain model evaluated may be responsible for the different response times documented. This test presented similar results to through acetic acid writhing, tail flick and tail immersion assays in mice to evaluate Chloroform and Methanol Extracts of Centella asiatica Linn as analgesics. ${ }^{31}$

Our results suggest that adequate antinociception (up to $150 \mathrm{~min}$ ) occurs after the repeated administration of methadone ( 4.3 and $5.7 \mathrm{mg} / \mathrm{kg}$ ), and is considered viable for pain treatment in cases of morphine tolerance in mice, ${ }^{16}$ and at lower doses than those tested in C57BL/6 mice, ${ }^{29}$ which demonstrated antinociception for only $80 \mathrm{~min}$. Therefore, the highest morphine or methadone doses tested in this study can promote antinociception and can be regarded as the choice for effective pain treatment in this experimental model. 


\subsection{CONCLUSION}

Our study supports the use of morphine or methadone as analgesic in BALB/c mice. The repeated administration of morphine, at doses of 5 and $7.5 \mathrm{mg} / \mathrm{kg}$, or methadone, at doses of 2.85 and $4.3 \mathrm{mg} / \mathrm{kg}$, can produce the desired prolonged antinociceptive effect. Furthermore, these substances promote behavioural changes, including increased locomotor activity and decreased exploratory behaviour. Despite these effects, we recommend the use of morphine or methadone in the doses of 10 and $5.7 \mathrm{mg} / \mathrm{kg}$, respectively, to treat cancer pain in mice.

\section{REFERENCES}

1. Abekawa T, Honda M, Ito K, Koyama T. 2003. Effects of NRA0045, a novel potent antagonist at dopamine D4, 5-HT 2A, and $\alpha 1$ adrenaline receptors, and NRA0160, a selective D4 receptor antagonist, on phencyclidine-induced behavior and glutamate release in rats. Psychopharmacology 169:247-256.

2. Audet MC, Goulet S, Doré FY. 2006. Repeated subchronic exposure to phencyclidine elicits excessive atypical grooming in rats. Behavioural Brain Research 167:103-110.

3. Barros HMT, Tannhauser SL, Tannhauser MAL, Tannhauser M. 1994. The Effects of GABAergic Drugs on Grooming Behaviour in the Open Field. Pharmacology and Toxicology. 74:339-344.

4. Belknap JK, Riggan J, Cross S, Young ER, Gallaher EJ, Crabbe JC. 1998. Genetic determinants of morphine activity and thermal responses in 15 inbred mouse strains. Pharmacology Biochemistry and Behavior. 59:353-360.

5. Bohn LM, Lefkowitz RJ, Gainetdinov RR, Peppel K, Caron MG, Lin FT. 1999. Enhanced morphine analgesia in mice lacking $\beta$-arrestin 2. Science. 286:2495-2498.

6. Calixto-Campos C, Zarpelon AC, Corrêa M, Cardoso RDR, Pinho-Ribeiro FA, Cecchini R, Moreira EG, Crespigio J, Bernardy CCF, Casagrande R. 2013. The Ehrlich Tumor Induces Pain-Like Behavior in Mice: A Novel Model of Cancer Pain for Pathophysiological Studies and Pharmacological Screening. BioMed Research International 2013:1-12.

7. Chiara G Di, Imperato A. 1986. Preferential Stimulation of Dopamine Release in the Nucleus Accumbens by Opiates, Alcohol, and Barbiturates: Studies with Transcerebral Dialysis in Freely Moving Rats. Annals of the New York Academy of Sciences. 473:367-381.

8. Deuis JR, Dvorakova LS, Vetter I. 2017. Methods used to evaluate pain behaviors in rodents. Frontiers in Molecular Neuroscience 10:1-17. 
9. Dowell D, Haegerich TM, Chou R. 2016. CDC guideline for prescribing opioids for chronic pain-United States, 2016. JAMA - Journal of the American Medical Association. 315:1624-1645.

10. Ferlay J, Soerjomataram I, Dikshit R, Eser S, Mathers C, Rebelo M, Parkin DM, Forman D, Bray F. 2015. Cancer incidence and mortality worldwide: Sources, methods and major patterns in GLOBOCAN 2012. International Journal of Cancer 136:E359-E386.

11. Fernandes PD, Guerra FS, Sales NM, Sardella TB, Jancar S, Neves JS. 2015. Characterization of the inflammatory response during Ehrlich ascitic tumor development. Journal of Pharmacological and Toxicological Methods 71:83-89.

12. Fukumasu H, Latorre AO, Zaidan-Dagli ML. 2011. Paullinia cupana Mart. var. sorbilis, guarana, increases survival of Ehrlich ascites carcinoma (EAC) bearing mice by decreasing cyclin-D1 expression and inducing a G0/G1 cell cycle arrest in EAC cells. Phytotherapy Research 25:11-16.

13. Geyer MA, Russo P V., Masten VL. 1986. Multivariate assessment of locomotor behavior: Pharmacological and behavioral analyses. Pharmacology, Biochemistry and Behavior 25:277-288.

14. Gray J, McNaughton N. 2003. Gray's Neuropsychology of anxiety: An enquiry into the functions of septohippocampal theories. 2nd ed. New York: Oxford University Press.

15. Grung M, Skurtveit S, Aasmundstad TA, Handal M, Alkana RL, Mørland J. 1998. Morphine-6-glucuronide-induced locomotor stimulation in mice: Role of opioid receptors. Pharmacology and Toxicology 82:3-10.

16. He L, Kim J, Ou C, McFadden W, Rijn RM van, Whistler JL. 2009. Methadone Antinociception Is Dependent on Peripheral Opioid Receptors. Journal of Pain 10:369379.

17. Hecht A, Schiorring E. 1979. Behavior Effects of Low and High Acute Doses of Morphine in Solitary Mice. Psychopharmacology 64:73-79.

18. Hnasko TS, Sotak BN, Palmiter RD. 2005. Morphine reward in dopaminedeficient mice. Nature. 438:854-857.

19. INCA. 2018. INCA - Câncer de Mama. Brasil [Internet]. [cited 2018 March 19]. Available from:

http://www2.inca.gov.br/wps/wcm/connect/tiposdecancer/site/home/mama/cancer_mam a

20. Kitanaka N, Kitanaka J, Hall FS, Kandori T, Murakami A, Muratani K, Nakano T, Uhl GR, Takemura M. 2018. Tetrabenazine, a vesicular monoamine transporter-2 inhibitor, attenuates morphine-induced hyperlocomotion in mice through alteration of dopamine and 5-hydroxytryptamine turnover in the cerebral cortex. Pharmacology Biochemistry and Behavior 172:9-16. 
21. Mantyh PW. 2006. Cancer pain and its impact on diagnosis, survival and quality of life. Nature Reviews Neuroscience 7:797-809.

22. McGowan JC, LaGamma CT, Lim SC, Tsitsiklis M, Neria Y, Brachman RA, Denny CA. 2017. Prophylactic Ketamine Attenuates Learned Fear.

Neuropsychopharmacology 42:1577-1589.

23. Mercadante S. 1997. Malignant bone pain: pathophysiology and treatment. Pain. 69:1-18.

24. Mercadante S, Bruera E. 2017. Methadone as a First-Line Opioid in Cancer Pain Management: A Systematic Review. Journal of Pain and Symptom Management 55:998-1003.

25. Middaugh LD, Ingram DK, Reynolds MA. 1983. Methadone effects on locomotor activity of young and aged mice. Neurobiology of Aging 4:157-161.

26. Onaolapo JO, Onaolapo YA, Akanmu AM, Olayiwola G. 2016. Caffeine and sleep-deprivation mediated changes in open-field behaviours, stress response and antioxidant status in mice. Sleep Science 9:236-243.

27. Ozaslan M, Karagoz ID, Kilic IH, Guldur ME. 2011. Ehrlich ascites carcinoma. African Journal of Biotechnology 10:2375-2378.

28. Pacharinsak C, Beitz AJ. 2008. Animal models of cancer pain. Comparative Medicine 58:220-233.

29. Pacifici R, Patrini G, Venier I, Parolaro D, Zuccaro P, Gori E. 1994. Effect of morphine and methadone acute treatment on immunological activity in mice:

pharmacokinetic and pharmacodynamic correlates. The Journal of pharmacology and experimental therapeutics 269:1112-1116.

30. Patti CL, Frussa-Filho R, Silva RH, Carvalho RC, Kameda SR, TakatsuColeman AL, Cunha JLS, Abílio VC. 2005. Behavioral characterization of morphine effects on motor activity in mice. Pharmacology Biochemistry and Behavior 81:923927.

31. Saha S, Guria T, Singha T, Maity TK. Evaluation of Analgesic and AntiInflammatory Activity of Chloroform and Methanol Extracts of Centella asiatica Linn . ISRN Pharmacology. 2013; 2013:1-6.

32. Seibenhener ML, Wooten MC. 2015. Use of the open field maze to measure locomotor and anxiety-like behavior in mice. Journal of Visualized Experiments 2015:1-6.

33. Shupak NM, Hensel JM, Cross-mellor SK, Kavaliers M, Prato FS, Thomas AW. 2004. Analgesic and behavioral effects of a $100 \mathrm{~m}$ T specific pulsed extremely low frequency magnetic field on control and morphine treated CF-1 mice 354:30-33.

34. Spruijt BM, Gispen WH. 1984. Behavioral sequences as an easily quantifiable parameter in experimental studies. Physiology and Behavior 32:707-710. 
35. Stojanović NM, Randjelović PJ, Radulović NS. 2017. Correlation between Two Parameters of Mice Behaviour in the Open Field Test. Acta Facultatis Medicae Naissensis 34:321-327.

36. Sturman O, Germain PL, Bohacek J. 2018. Exploratory rearing: a context- and stress-sensitive behavior recorded in the open-field test. Stress 21:443-452.

37. Tanaka S, Young JW, Halberstadt AL, Masten VL, Geyer MA. 2012. Four factors underlying mouse behavior in an open field. Behavioural Brain Research 233:55-61.

38. Varela MJ, Acanda de la Rocha AM, Díaz A, Lopez-Gimenez JF. 2017.

Potentiation of morphine-induced antinociception and locomotion by citalopram is accompanied by anxiolytic-like effects. Pharmacology Biochemistry and Behavior 163:83-89.

39. WHO. 2017. Cancer - Diagnosis and Treatment. WHO [Internet]. [cited 2018 March 15]. Available from: http://www.who.int/cancer/treatment/en/

40. Wolf S, Barton D, Kottschade L, Grothey A, Loprinzi C. 2008. Chemotherapyinduced peripheral neuropathy: Prevention and treatment strategies. European Journal of Cancer 44:1507-1515.

41. Zylla D, Steele G, Gupta P. 2017. A systematic review of the impact of pain on overall survival in patients with cancer. Support Care Cancer 25:1687-1698. 


\section{ESTUDO 2 - MORFINA E METADONA REDUZEM O VOLUME E PROMOVEM ESTASE NO CICLO CELULAR EM CAMUNDONGOS COM TUMOR DE EHRLICH}

\section{RESUMO}

A ampla utilização da morfina e da metadona como analgésicos em pacientes oncológicos tem sido relacionada com possíveis efeitos pró e anti-tumorais a depender do período de tratamento e tipo de tumor. O estudo avaliou os efeitos da morfina e metadona sobre o crescimento do tumor ascítico de Ehrlich em camundongos. Foram utilizados 58 camundongos BALB/c, fêmeas, com $60 \pm 10$ dias de idade. Após 24 horas da inoculação tumoral ( $2 \times 10^{6}$ células) via intraperitoneal, os animais foram distribuídos aleatoriamente em sete grupos: morfina $5 \mathrm{mg} / \mathrm{kg}$ (Morf 5 ), morfina 7,5 $\mathrm{mg} / \mathrm{kg}\left(\operatorname{Morf}_{7,5}\right)$, morfina $10 \mathrm{mg} / \mathrm{kg}\left(\operatorname{Morf}_{10}\right)$, metadona 2,85 mg/kg (Met 2,85$)$, metadona 4,3 mg/kg (Met 4,3 ), metadona 5,7 mg/kg (Met 5,7$)$ e solução salina $\mathrm{NaCl}$ 0,9\% (Salina). Os tratamentos foram administrados por via subcutânea, a cada 6 horas, durante oito dias. Os animais foram avaliados diariamente quanto ao peso e circunferência abdominal e, nove dias após a inoculação tumoral, foram submetidos a eutanásia. $\mathrm{O}$ líquido ascítico foi colhido para mensuração do volume, verificação da característica do líquido, contagem de células tumorais e análise do ciclo celular. Todos os animais apresentaram aumento de peso e de circunferência abdominal ao longo dos dias. $\mathrm{O}$ volume do líquido ascítico peritoneal foi menor nos tratamentos Morf5, Morf 10 e em todas as doses testadas de metadona em comparação ao grupo Salina. Foi possível determinar que os tratamentos com morfina e metadona aumentaram significativamente a porcentagem de células em $\mathrm{G} 0 / \mathrm{G} 1$, o que condiz com o menor desenvolvimento tumoral observado a partir do menor volume ascítico (peso, circunferência e volume tumoral) e menor grau de hemorragia na maior dose de morfina. Embora existam evidências de atividade de estase no ciclo celular pela morfina e metadona, os resultados não são consistentes, visto que viabilidade e o número de células totais não diferiram entre os tratamentos. Dessa maneira, visualizou-se que a morfina e a metadona quando administradas de forma prolongada não alteram o crescimento do tumor ascítico de Ehrlich.

Palavras-chave: opioides; ciclo celular; crescimento tumoral.

\subsection{INTRODUÇÃO}

O câncer de mama é o tipo de tumor mais prevalente em mulheres e perfaz a principal causa de morte por câncer nas pacientes acima de 35 anos, em todo o mundo (FERLAY et al., 2010; INCA, 2019). A dor oncológica está presente em mais de 50\% dos pacientes com câncer e relaciona-se com a localização anatômica e a fisiopatologia do tumor, além do tratamento cirúrgico ou medicamentoso (VAN DEN BEUKEN-VAN EVERDINGEN et al., 2016). Ainda, mediadores químicos e quimiocinas são secretados pelas células tumorais e pelo tecido invadido, o que agrava o quadro álgico (FALK; BANNISTER; DICKENSON, 2014). 
A escolha de um protocolo analgésico eficiente está estritamente relacionado ao aumento da qualidade e da sobrevida de pacientes com câncer e atualmente a eleição de fármacos que não favoreçam o crescimento tumoral tem se tornado uma preocupação recorrente (SWARM et al., 2019). Embora a morfina seja considerada o analgésico opioide de primeira escolha para o tratamento da dor oncológica, evidências apontam para ações imunossupressoras (ODUNAYO et al., 2010) e pró-tumorais a depender da dose, frequência, período de utilização e tipo de tumor (GACH et al., 2011). A morfina parece promover supressão e redução da citotoxicidade de células natural killers (NK), efeito que tende a ser mais importante em pacientes oncológicos, pois está relacionada ao aumento do crescimento tumoral e ocorrência de metástases em camundongos (GASPANI et al., 2002; SHAVIT et al., 2004). Além da imunossupressão, a morfina parece promover o desenvolvimento de mecanismos facilitadores de metástases (YU et al., 2019) e neovascularização de tumores (GUPTA et al., 2002). Em contrapartida, altas concentrações plasmáticas de morfina $(>10 \mu \mathrm{M})$ promoveram redução do crescimento de células de MCF-7 e MDA-MB231 em camundongos nude (TEGEDER et al., 2003).

A metadona é um outro opioide amplamente utilizado para terapia oncológica, especialmente em casos de tolerância e dependência a morfina (FALLON et al., 2018; MERCADANTE; BRUERA, 2017). Embora ela também ocupe receptores $\mu$ opioides, assim como a morfina, verificou-se que camundongos C57BL/6 tratados com uma dose de $12,5 \mathrm{mg} / \mathrm{kg}$ tiveram a função imunológica preservada (PACIFICI et al., 1994). Ainda, em indivíduos dependentes de heroína, o tratamento com metadona restaurou a função imunológica para níveis normais (SACERDOTE et al., 2008). Ainda que seus efeitos em células do tumor de Ehrlich não tenham sido testados, efeitos de inibição tumoral e potencialização dos efeitos de quimioterápicos após a utilização de metadona já foram evidenciados em células de glioblastoma (FRIESEN et al., 2013, 2014). O tumor de Ehrlich é uma linhagem tumoral derivada de adenocarcinoma mamário que acomete espontaneamente camundongos (TYZZER, 1910). Quando inoculado por via intraperitoneal prolifera-se de forma ascítica e a contagem celular permite a avaliação quantitativa dos efeitos de fármacos sobre o tumor (MAYER, 1966). Seu desenvolvimento se dá em virtude do aumento da permeabilidade vascular, bem como recrutamento de neutrófilos e macrófagos pelas células cancerígenas que liberam citocinas e amplificam a resposta imunológica (FASTAIA; DUMONT, 1976).

O objetivo do presente estudo foi avaliar se a morfina e metadona administradas de maneira prolongada influenciam no crescimento do tumor ascítico de 
Ehrlich (TAE) em camundongos.

\subsection{MATERIAL E MÉTODOS}

\subsubsection{Animais}

Todos os procedimentos foram realizados de acordo com a Comissão de Ética no Uso de Animais da Faculdade de Zootecnia e Engenharia de Alimentos da Universidade de São Paulo (3836220518/2018).

Foram utilizados 60 camundongos da linhagem BALB/cJ, fêmeas com $60 \pm 10$ dias de idade e $25 \pm 5$ gramas provenientes do biotério do Departamento de Patologia da Faculdade de Medicina Veterinária e Zootecnia da Universidade de São Paulo. Os animais foram alojados em biotério específico, dispostos aleatoriamente em gaiolas (37 x 22 x $15 \mathrm{~cm}$ ) com três a quatro animais, em condições de temperatura controlada (22$23^{\circ} \mathrm{C}$ ), ciclo claro/escuro de 12 horas, com luzes acesas as 06h30min e água e ração (Nuvital ${ }^{\circledR}$, Quimtia, Paraná, Brasil) disponíveis ad libitum. Os animais foram ambientados nas instalações por pelo menos 10 dias, antes do início experimento.

\subsubsection{Fármacos}

Sulfato de morfina (Dimorf ${ }^{\circledR}$, Cristália, São Paulo, Brazil) e cloridrato de metadona (Mytedon ${ }^{\circledR}$, Cristália, São Paulo, Brazil).

\subsubsection{Desenho experimental}

Os animais dos grupos experimentais receberam $2 \times 10^{6}$ células tumorais de Ehrlich, por via intraperitoneal, provenientes de um camundongo doador (4 animais). Após 24 horas da inoculação tumoral os animais foram distribuídos aleatoriamente em sete grupos: morfina $5 \mathrm{mg} / \mathrm{kg}$ (Morf5), morfina 7,5 mg/kg (Morf 7,5$)$, morfina $10 \mathrm{mg} / \mathrm{kg}$ $\left(\right.$ Morf $\left._{10}\right)$, metadona 2,85 mg/kg (Met 2,85$)$, metadona 4,3 mg/kg (Met 4,3$)$, metadona 5,7 $\mathrm{mg} / \mathrm{kg}\left(\right.$ Met $\left._{5,7}\right)$ e solução salina $\mathrm{NaCl}$ 0,9\% (Salina) $(\mathrm{n}=8)$. Os tratamentos foram administrados por via subcutânea, a cada 6 horas, durante oito dias. As doses de morfina foram escolhidas com base na literatura (CALIXTO-CAMPOS et al., 2013; HECHT; SCHIORRING, 1979) e as de metadona, de acordo com a equipotência de 1,75 vezes em relação a morfina (MERCADANTE; BRUERA, 2017). O volume final de cada tratamento foi padronizado em $0,3 \mathrm{~mL}$ de solução, ajustado com $\mathrm{NaCl} 0,9 \%$. 
Diariamente, no mesmo horário, os animais foram pesados em balança de precisão e a circunferência abdominal aferida por meio de fita métrica. Após 8 dias de tratamento os animais foram submetidos à eutanásia, em câmara de $\mathrm{CO}_{2}$. $\mathrm{O}$ conteúdo ascítico dos camundongos foi colhido imediatamente após a eutanásia, até que todo o líquido abdominal fosse aspirado. Imediatamente, o volume foi contabilizado na própria seringa e avaliado quanto a presença de exsudato hemorrágico, pontuando-o em 0 líquido amarelado sem presença de hemácias, 1 - líquido turvo com leve coloração avermelhada, 2 - líquido avermelhado e 3 - coloração vermelha intensa (FUKUMASU; LATORRE; ZAIDAN-DAGLI, 2011). Após, as amostras foram armazenadas em tubo plástico do tipo Falcon de $10 \mathrm{~mL}$ e mantidas em isopor com gelo por 2 horas até que as análises fossem efetuadas. Para a contagem celular, foram pipetados $3 \mu \mathrm{L}$ do líquido peritoneal, depositados em um tubo do tipo Eppendorf contendo $297 \mu \mathrm{L}$ de azul de Tripan (0,5\%) (Sigma, St Louis, MO, EUA). Após homogeneização, foram pipetados $10 \mu \mathrm{L}$ da solução e depositados em câmara de Neubauer para a contagem celular. A contagem celular foi realizada por meio de microscópio óptico com aumento de 40x, sendo contabilizadas as células redondas maiores presentes nos quadrantes superior esquerdo e inferior direito.

Para o ciclo celular, 1 × $10^{6}$ células do carcinoma ascítico de Ehrlich de cada animal foram depositadas em um tubo do tipo Falcon contendo $3 \mathrm{~mL}$ de álcool absoluto e $1 \mathrm{~mL}$ de tampão fosfato salino (PBS) e então, conservadas em freezer $-20^{\circ} \mathrm{C}$. Em aproximadamente 30 dias as células foram lavadas três vezes em PBS, centrifugadas por 5 minutos a $1200 \mathrm{rpm}$ e incubadas em $1000 \mu \mathrm{L}$ de solução de PBS contendo $20 \mu \mathrm{g} / \mathrm{mL}$ de iodeto de propídio (Sigma, St Louis, MO, EUA), $200 \mu \mathrm{g} / \mathrm{mL}$ de RNAse A (Invitrogen Biotechnology, Carlsbad, CA, EUA) e solução de Triton a 0,1\% (Sigma, St Louis, MO, EUA) em tubos de ensaio de $5 \mathrm{~mL}$. Após $30 \mathrm{~min}$ de incubação no escuro, 10000 eventos por segundo foram adquiridos por citometria de fluxo citômetro de fluxo S3 cell sorter (Bio-rad EUA) usando o filtro FL-2 $(585 \pm 42 \mathrm{~nm})$. Os dados foram analisados pelo software FCS Express 7.0 ${ }^{\circledR}$ (De Novo Software, Thornhill, Ontario, Canadá) e os resultados expressos como \% de células nas fases G0/G1, S ou G2/M.

\subsubsection{Análise estatística}

Os dados foram analisados com o software estatístico GraphPad Prism 7.0. A distribuição dos dados foi verificada pelo teste de Shapiro-Wilk. As variáveis peso e 
circunferência abdominal foram avaliadas quanto a variância (2-way ANOVA) e pós teste de Dunnet para comparações ao longo do tempo. A comparação entre os tratamentos das variáveis viabilidade, volume do líquido ascítico, hemorragia no líquido ascítico, células totais e percentagem das fases do ciclo celular foram analisados quanto a variância (ANOVA) e pós teste de Dunnet. O número de células/mL foi avaliado com Kruskall-Wallis e Dunn para comparação dos tratamentos em relação ao grupo Salina. A correlação entre o peso e a circunferência abdominal foi analisada por meio da correlação de Pearson. O nível de significância adotado foi de 5\% ( $<<0,05)$.

\subsection{RESULTADOS}

Após a inoculação tumoral verificou-se que todos os animais desenvolveram tumor ascítico de Ehrlich e não houve nenhum óbito antes do final do período experimental. O peso e a circunferência abdominal aumentaram ao longo dos dias em decorrência do crescimento tumoral $(p<0,0001)$. Nos dias 7 e 8 o peso foi menor nos grupos Morf $_{10}$, Met $_{4,3}$ e Met5,7 em relação ao grupo Salina e também em Met5,7 no dia 9 (Figura 1). Houve correlação entre o peso e a circunferência abdominal $r=0,83$ (p <0 $0,0001)$ e o volume $r=0,39(\mathrm{p}=0,0023)$.

Não foram observadas diferenças na viabilidade das células tumorais entre os grupos. Todos, exceto $\operatorname{Morf}_{7,5}$, apresentaram volume de líquido peritoneal menor do que os animais do grupo Salina $(p<0,0206)$ (Figura 2A). O número de células tumorais totais foi semelhante entre os grupos (Figura 2C). Foi notado menor nível de hemorragia do líquido ascítico colhido dos animais do grupo Morf 10 em comparação aos do grupo Salina. 
1 Figura 6.1 - Avaliação do peso (em gramas) e da circunferência abdominal (em centímetros) de camundongos fêmeas BALB/c inoculados com 2 células do carcinoma ascítico de Ehrlich e tratados com $\mathrm{NaCl}$ 0,9\% (Salina), diferentes doses de morfina ou metadona durante oito dias. Valores 3 expressos em média \pm erro padrão $(\mathrm{n}=8)$. * Valores considerados diferentes quando comparados ao grupo Salina $(\mathrm{p}<0,05)$.
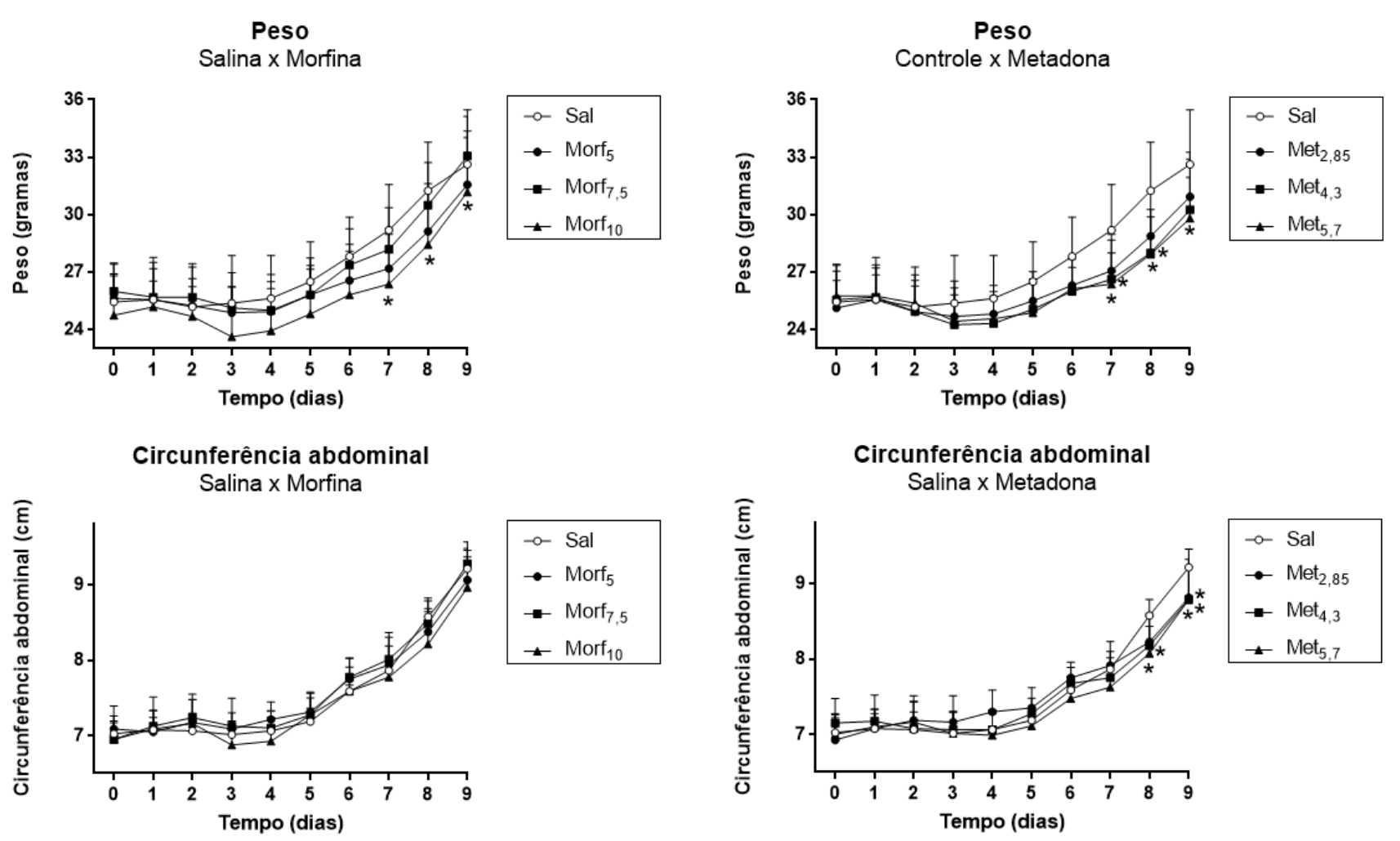

4 Fonte: própria autoria. 
Figura 6.2 - Volume do líquido peritoneal (A), células por mL (B) e células totais (C) após nove dias de crescimento do tumor ascítico de Ehrlich em camundongos BALB/c tratados com solução salina (Sal), diferentes doses de morfina ou metadona.
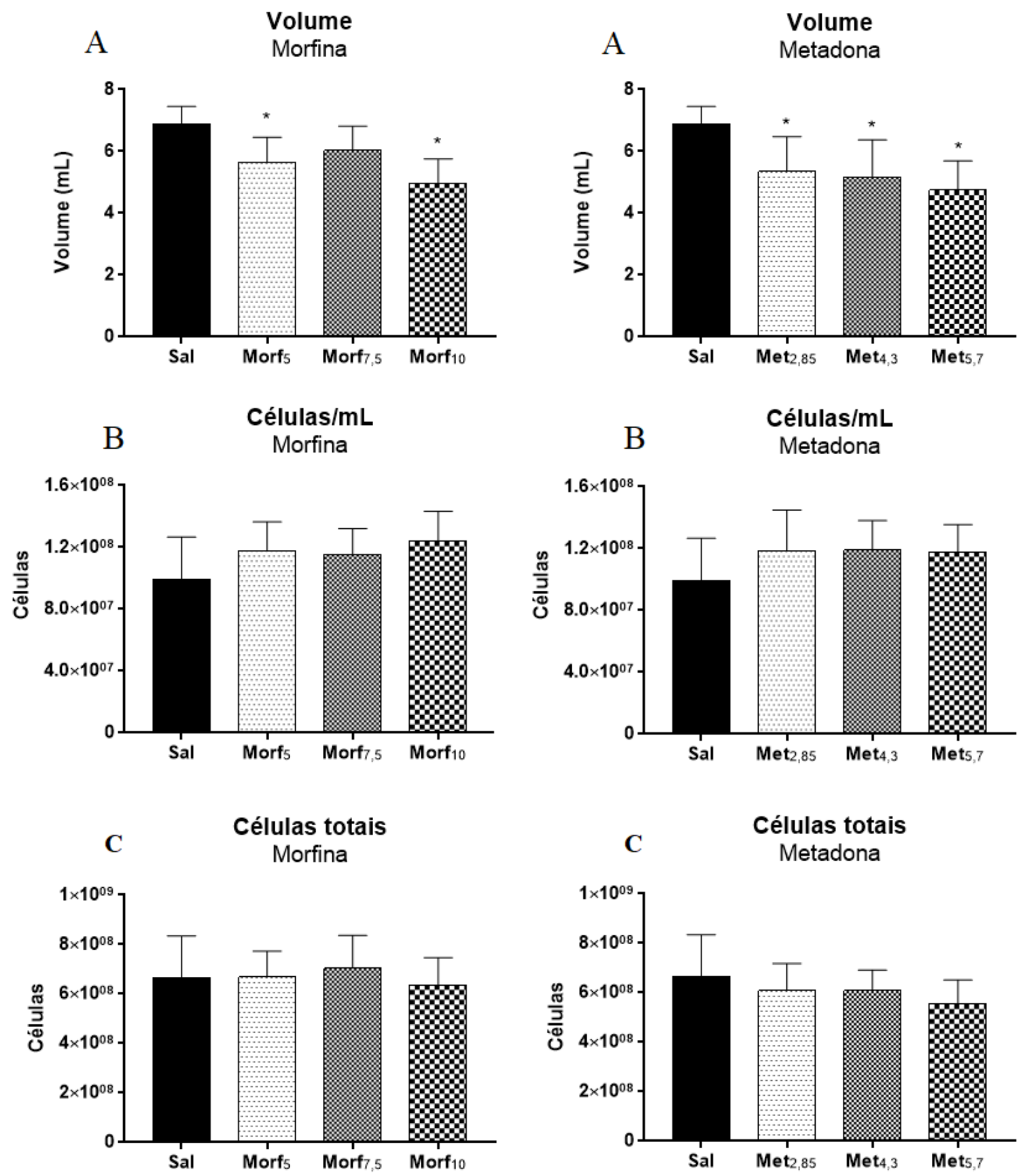

Fonte: própria autoria 
Para análise do ciclo celular, foram avaliadas apenas as amostras dos animais do grupo Salina e as maiores doses de metadona e morfina. Foi possível determinar que os tratamentos com morfina e metadona aumentaram significativamente a porcentagem de células em G0/G1 $(p<0,0024)$ (Figura 3).

Figura 6.3 - Porcentagem de células tumorais em fases do ciclo celular G0/G1, S, G2/M, de camundongos submetidos 8 dias após tratamento de morfina e metadona ou solução salina. * $\mathrm{p}<0,05$, ANOVA seguido do teste de Tukey.

Ciclo Celular

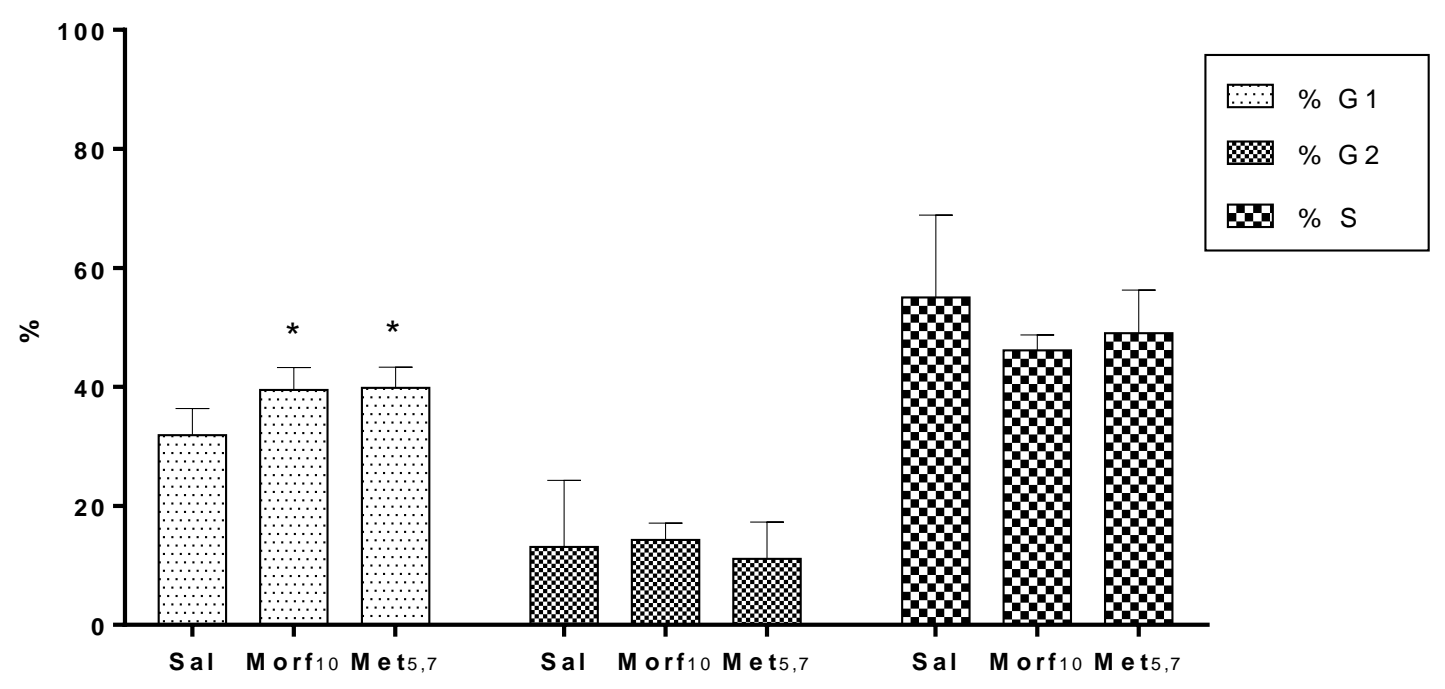

Fonte: própria autoria.

\subsection{DISCUSSÃO}

Esse estudo demonstrou que os tratamentos com morfina e metadona podem interferir no processo de desenvolvimento tumoral na formação da coleção do líquido ascítico. Esse processo foi visualizado por meio do menor aumento do ganho do peso e circunferência abdominal e menor volume de líquido ascítico colhido após eutanásia nos grupos tratados com opioides em comparação ao grupo Salina. Houve correlação do aumento de peso com a circunferência abdominal e com o aumento de volume, o que indica que o aumento de peso esteve relacionado com o crescimento do tumor de forma ascítica.

Ainda, o escore de hemorragia ascítica foi menor no grupo tratado com a maior dose de morfina, o que indica menor grau de acometimento tumoral (HARTVEIT, 1961). Foi demonstrado também que as células tumorais de animais tratados com morfina e metadona 
proliferaram de forma menos intensa que o grupo Salina já que houve maior porcentagem de células na fase G1 do ciclo celular.

O tumor de Ehrlich é um modelo tumoral agressivo, com alta proliferação e sem remissão (MAYER, 1966). A medida que o tumor progride, há aumento na expressão da enzima ciclo-oxigenase-1 (COX-1), prostaglandina E2 e óxido nítrico. Sua característica inflamatória valida-o como modelo para triagem de medicamentos antitumorais (FERNANDES et al., 2015). Constatou-se que todas as doses de metadona promoveram redução do volume ascítico, assim como a menor e a maior dose de morfina. A redução do volume ascítico está relacionada a alteração da permeabilidade vascular, bem como em função do comprometimento da drenagem linfática da região (FERNANDES et al., 2015). Essa redução da permeabilidade vascular também foi identificada após administração de fármacos inibidores de COX-1, como a cortisona (FASTAIA; DUMONT, 1976). Embora a redução da quantidade do líquido ascítico não esteja diretamente relacionada a redução da carga tumoral, pode aumentar a sobrevida dos animais. Isso ocorre, pois, o óbito dos animais está relacionado ao aumento da pressão abdominal, anemia causada pela hemorragia ascítica e desequilíbrio eletrolítico devido ao extravasamente para o meio peritoneal (HARTVEIT, 1965).

Outro ponto interessante observado, foi a redução da hemorragia do líquido ascítico na maior dose testada de morfina em comparação ao grupo Salina, que indica menor grau de acometimento dos animais pelo tumor (HARTVEIT, 1961). Suspeita-se que um dos mecanismos envolvidos na redução do líquido ascítico e da redução da hemorragia ascítica seja devido à redução da inflamação pela redução da expressão de PGE-2 pela morfina, já visualizado em sinoviócitos de equinos estimulados in vitro com LPS e tratados com morfina (SCHWARZBACH et al., 2019).

Substâncias com potencial efeito antitumoral devem promover redução da viabilidade celular por meio de apoptose ou estase do ciclo celular (LISBOA et al., 2020; MANSOUR et al., 2019; NISHITANI; LYGEROU, 2002). No presente estudo, tanto a morfina quanto a metadona promoveram maior proporção de células na fase G0/G1 do ciclo celular, o que representa estase no ciclo para que as células tenham tempo para reparar danos em seu DNA ou entrar em apoptose (NISHITANI; LYGEROU, 2002). Outro estudo verificou também verificou que a morfina causou redução da proliferação celular e morte de células de adenocarcinoma mamário por meio da por inibição da progressão do ciclo celular da fase G1 para S (TEGEDER et al., 2003). Ainda, demonstrou redução do crescimento dos tumores em modelos de ratos Fisher com câncer de cólon (YEAGER; COLACCHIO, 1991) e em 
camundongos C57BL6 com câncer de cólon (HARIMAYA et al., 2002). Já a metadona foi testada em combinação com quimioterápicos com bons resultados em pacientes com glioblastoma (FRIESEN et al., 2014) e em células leucêmicas (FRIESEN et al., 2013). No entanto, a administração prolongada tem sido associada ao aumento da carga tumoral em diferentes estudos (CHENG et al., 2006; ISHIKAWA et al., 1993; USTUN et al., 2011).

As evidências do estudo apontam para um possível efeito antiproliferativo das maiores doses de morfina e metadona sobre as células do tumor ascítico de Ehrlich. No entanto, os resultados não foram consistentes, frente a ausência da redução da viabilidade e do número de células totais não ser diferente entre os tratamentos.

\subsection{CONCLUSÃO}

O estudo demonstrou que a morfina e a metadona interferem na proliferação celular de células do carcinoma ascítico de Ehrlich, no entanto, sua administração durante 8 dias não foi suficientemente capaz de influenciar significativamente no crescimento desse tipo de tumor na forma ascítica.

\section{REFERÊNCIAS}

CALIXTO-CAMPOS, C. et al. The Ehrlich Tumor Induces Pain-Like Behavior in Mice: A Novel Model of Cancer Pain for Pathophysiological Studies and Pharmacological Screening.

BioMed Research International, v. 2013, p. 1-12, 2013.

CHENG, W. F. et al. Chimeric DNA vaccine reverses morphine-induced immunosuppression and tumorigenesis. Molecular Therapy, v. 13, n. 1, p. 203-210, 2006.

FALK, S.; BANNISTER, K.; DICKENSON, A. H. Cancer pain physiology. British Journal of Pain, v. 8, n. 4, p. 154-162, 2014.

FALLON, M. et al. Management of cancer pain in adult patients: ESMO Clinical Practice Guidelines. Annals of Oncology, v. 29, n. July, p. iv166-iv191, 2018.

FASTAIA, J.; DUMONT, A. E. Pathogenesis Of Ascites In Mice With Peritoneal Carcinomatosis. Journal of the National Cancer Institute, v. 56, n. 3, p. 547-550, 1976.

FERLAY, J. et al. Estimates of worldwide burden of cancer in 2008: GLOBOCAN 2008. International Journal of Cancer, v. 127, n. 12, p. 2893-2917, 15 dez. 2010.

FERNANDES, P. D. et al. Characterization of the inflammatory response during Ehrlich ascitic tumor development. Journal of Pharmacological and Toxicological Methods, v. 71, p. 83-89, 1 jan. 2015.

FRIESEN, C. et al. Cell death sensitization of leukemia cells by opioid receptor activation. 
Oncotarget, v. 4, n. 5, p. 677-690, 2013.

FRIESEN, C. et al. Opioid receptor activation triggering downregulation of cAMP improves effectiveness of anti-cancer drugs in treatment of glioblastoma. Cell Cycle, v. 13, n. 10, p. 1560-1570, 2014.

FUKUMASU, H.; LATORRE, A. O.; ZAIDAN-DAGLI, M. L. Paullinia cupana Mart. var. sorbilis, guarana, increases survival of Ehrlich ascites carcinoma (EAC) bearing mice by decreasing cyclin-D1 expression and inducing a G0/G1 cell cycle arrest in EAC cells. Phytotherapy Research, v. 25, n. 1, p. 11-16, 1 jan. 2011.

GACH, K. et al. The role of morphine in regulation of cancer cell growth. NaunynSchmiedeberg's Archives of Pharmacology, v. 384, n. 3, p. 221-230, 2011.

GASPANI, L. et al. The analgesic drug tramadol prevents the effect of surgery on natural killer cell activity and metastatic colonization in rats. Journal of Neuroimmunology, v. 129, n. 1-2, p. 18-24, 2002.

GUPTA, K. et al. Morphine stimulates angiogenesis by activating proangiogenic and survival-promoting signaling and promotes breast tumor growth. Cancer Research, v. 62, n. 15, p. 4491-8, 2002.

HARIMAYA, Y. et al. Potential ability of morphine to inhibit the adhesion, invasion and metastasis of metastatic colon 26-L5 carcinoma cells. Cancer Letters, v. 187, n. 1-2, p. 121$127,2002$.

HARTVEIT, F. The Significance of the Blood Content of the Bergen A4 Mouse Ascites Carcinoma. British Journal of Cancer, v. 18, n. 3, p. 557-563, set. 1961.

HARTVEIT, F. The immediate cause of death in mice with Ehrlich's ascites carcinoma. Acta pathologica et microbiologica Scandinavica, v. 65, n. 3, p. 359-365, 1965.

HECHT, A.; SCHIORRING, E. Behavior Effects of Low and High Acute Doses of Morphine in Solitary Mice. Psychopharmacology, v. 64, p. 73-79, 1979.

INCA. INCA. Disponível em: <https://www.inca.gov.br/estimativa/estado-capital/brasil>. Acesso em: 10 mar. 2020.

ISHIKAWA, M. et al. Enhancement of Tumor Growth by morphine and its possible mechanism in mice. Biological and Pharmaceutical Bulletin, v. 16, n. 8, p. 762-766, 1993.

LISBOA, T. et al. Toxicity and antitumor activity of a thiophene-acridine hybrid. Molecules, v. 25 , n. $1,2020$.

MANSOUR, M. A. et al. Combination of arsenic trioxide and cisplatin synergistically inhibits both hexokinase activity and viability of Ehrlich ascites carcinoma cells. Journal of

Biochemical and Molecular Toxicology, v. 33, n. 8, p. 1-11, 2019.

MARTUCCI, C. et al. Differential involvement of RelB in morphine-induced modulation of chemotaxis, NO, and cytokine production in murine macrophages and lymphocytes. Journal 
of Leukocyte Biology, v. 81, n. 1, p. 344-354, 2007.

MAYER, K. D. The pathogenicity of the Ehrlich ascites tumour. British Journal of Experimental Pathology, v. 47, n. 5, p. 537-544, 1966.

MERCADANTE, S.; BRUERA, E. Methadone as first line opioid in cancer pain management: a systematic review. Journal of Pain and Symptom Management, 2017.

NISHITANI, H.; LYGEROU, Z. Control of DNA replication licensing in a cell cycle. Genes to Cells, v. 7, n. 6, p. 523-534, 2002.

ODUNAYO, A. et al. Immunomodulatory effects of opioids. Journal of Veterinary Emergency and Critical Care, v. 20, n. 4, p. 376-385, 2010.

SCHWARZBACH, S. V. et al. Morphine, but not methadone, inhibits microsomal prostaglandin E synthase-1 and prostaglandin-endoperoxide synthase 2 in lipopolysaccharidestimulated horse synoviocytes. Biochimie, v. 160, p. 28-33, maio 2019.

SHAVIT, Y. et al. Effects of fentanyl on natural killer cell activity and on resistance to tumor metastasis in rats: Dose and timing study. Neuroimmunomodulation, v. 11, n. 4, p. 255-260, 2004.

SWARM, R. A. et al. Adult cancer pain, version 3.2019. Journal of the National Comprehensive Cancer Network, v. 17, n. 8, p. 977-1007, 2019.

TEGEDER, I. et al. G protein-independent G1 cell cycle block and apoptosis with morphine in adenocarcinoma cells: Involvement of p53 phosphorylation. Cancer Research, v. 63, n. 8, p. 1846-1852, 2003.

TYZZER, E. E. A study of inheritance in mice with reference to their susceptibility to transplantable tumours. Zeitschrift für Induktive Abstammungs- und Vererbungslehre, v. 4, n. 1, p. 296-297, 1910.

USTUN, F. et al. Evaluation of morphine effect on tumour angiogenesis in mouse breast tumour model, EATC. Medical Oncology, v. 28, n. 4, p. 1264-1272, 2011.

VAN DEN BEUKEN-VAN EVERDINGEN, M. H. J. et al. Update on Prevalence of Pain in Patients with Cancer: Systematic Review and Meta-Analysis. Journal of Pain and Symptom Management, v. 51, n. 6, p. 1070- 1090.e9, 2016.

YEAGER, M. P.; COLACCHIO, T. A. Effect of Morphine on Growth of Metastatic Colon Cancer In Vivo. Archives of Surgery, v. 126, n. 4, p. 454-456, 1991.

YU, W. et al. Cadherin Signaling in Cancer: Its Functions and Role as a Therapeutic Target. Frontiers in Oncology, v. 9, n. October, 2019. 


\section{CONCLUSÕES}

- Houve aumento da atividade locomotora no campo aberto com pico de ação de todos os tratamentos aos 40 minutos, que se prorrogaram por até 90 minutos no em todas as doses testadas de morfina e a maior dose de metadona no dia 7, em relação ao grupo Salina. Houve aumento da atividade locomotora nos dias 8 e 9 em comparação com o dia 7. Não houve diferença significativa entre a morfina e a metadona.

- As frequências de grooming e de levantar foram reduzidas significativamente pelos tratamentos, sendo que o grooming foi reduzido por até 90 minutos e a frequência de levantar por até 150 minutos em todas as doses testadas.

- O período de antinocicepção promovido pelos fármacos foi de até 90 minutos nas menores doses testadas de morfina e metadona e até 150 minutos na dose de $10 \mathrm{mg} / \mathrm{kg}$ de morfina. Não foi possível afirmar efeito cumulativo dos fármacos no modelo de dor testado.

- A morfina e a metadona reduziram a formação de fluido ascítico por meio da redução do volume do líquido. No entanto, não interferiram no número de células/mL e totais.

- A morfina e a metadona nas maiores doses promoveram estase do ciclo celular na fase G1 do ciclo. 


\section{CONSIDERAÇÕES FINAIS}

Para o controle adequado da dor oncológica são necessárias administrações seriadas de fármacos opioides com o intuito de manter a concentração plasmática e consequentemente proporcionar bem-estar ao paciente. No entanto, os efeitos desencadeados por esses fármacos no comportamento animal devem ser conhecidos, afim de evitar erros na identificação e tratamento da dor. Dessa forma, observou-se que todas as doses testadas promovem antinocicepção em camundongos por até 150 minutos após administrações seriadas. Ainda, promovem alterações comportamentais com aumento da locomoção e redução de comportamentos exploratórios. Identificamos que uma das limitações do estudo foi a utilização de doses baixas de metadona, em virtude do cálculo de equipotência realizado. Outro fator foi a distribuição aleatória dos animais nas gaiolas, o que impossibilitou a mensuração do consumo de água e ração de cada tratamento. Ainda, considerou-se que o teste de pinçamento de cauda não tenha traduzido a dor oncológica presente nos animais e a avaliação da expressão facial pudesse ser mais fidedigna para a situação.

No que se referiu aos efeitos desses fármacos no crescimento tumoral, constatou-se que a morfina e a metadona administradas de maneira seriada, durante oito dias interferem na proliferação celular. No entanto, a viabilidade celular e o número de células totais não diferiu entre os tratamentos, o que demonstra que seus efeitos não foram significativamente relevantes no crescimento do tumor ascítico. Nesse experimento uma das limitações foi a ausência da dosagem de citocinas e prostaglandinas, que poderiam demonstrar que a redução do volume e estase do ciclo tenham sido promovidas por um possível efeito anti-inflamatório dos opioides.

Assim, a morfina e a metadona foram considerados fármacos adequados para o tratamento da dor em camundongos com dor oncológica, desde que sua posologia e intervalo de tratamento sejam respeitados. 


\section{REFERÊNCIAS}

ABEKAWA, T. et al. Effects of NRA0045, a novel potent antagonist at dopamine D 4 , 5-HT 2A, and $\alpha 1$ adrenaline receptors, and NRA0160, a selective D 4 receptor antagonist, on phencyclidine-induced behavior and glutamate release in rats. Psychopharmacology, v. 169, n. 3-4, p. 247-256, 2003.

AUDET, M. C.; GOULET, S.; DORÉ, F. Y. Repeated subchronic exposure to phencyclidine elicits excessive atypical grooming in rats. Behavioural Brain Research, v. 167, n. 1, p. 103-110, 2006.

BARROS, H. M. T. et al. The Effects of GABAergic Drugs on Grooming Behaviour in the Open Field. Pharmacology and Toxicology, v. 74, p. 339-344, 1994.

BASBAUM, A. I. et al. Cellular and Molecular Mechanisms of Pain. Cell, v. 139, n. 2, p. 267-284, out. 2009.

BELKNAP, J. K. et al. Genetic determinants of morphine activity and thermal responses in 15 inbred mouse strains. Pharmacology Biochemistry and Behavior, v. 59, n. 2, p. 353-360, 1998.

BIMONTE, S. et al. Morphine Promotes Tumor Angiogenesis and Increases Breast Cancer Progression. BioMed Research International, v. 2015, 2015.

BOHN, L. M. et al. Enhanced morphine analgesia in mice lacking $\beta$-arrestin 2. Science, v. 286, n. 5449, p. 2495-2498, 1999.

CALIXTO-CAMPOS, C. et al. The Ehrlich Tumor Induces Pain-Like Behavior in Mice: A Novel Model of Cancer Pain for Pathophysiological Studies and Pharmacological Screening. BioMed Research International, v. 2013, p. 1-12, 2013.

CHAPMAN, C. R.; VIERCK, C. J. The Transition of Acute Postoperative Pain to Chronic Pain: An Integrative Overview of Research on Mechanisms. Journal of Pain, v. 18, n. 4, p. 359.e1-359.e38, 2017.

CHENG, W. F. et al. Chimeric DNA vaccine reverses morphine-induced immunosuppression and tumorigenesis. Molecular Therapy, v. 13, n. 1, p. 203-210, 2006.

DEUIS, J. R.; DVORAKOVA, L. S.; VETTER, I. Methods used to evaluate pain behaviors in rodents. Frontiers in Molecular Neuroscience, v. 10, n. September, p. 1-17, 2017.

DI CHIARA, G.; IMPERATO, A. Preferential Stimulation of Dopamine Release in the Nucleus Accumbens by Opiates, Alcohol, and Barbiturates: Studies with Transcerebral Dialysis in Freely Moving Rats. Annals of the New York Academy of Sciences, v. 473, n. 1, p. 367-381, 1986.

DOWELL, D.; HAEGERICH, T. M.; CHOU, R. CDC guideline for prescribing opioids for chronic pain-United States, 2016. JAMA - Journal of the American Medical Association, v. 315 , n. 15, p. 1624-1645, 2016. 
ELMORE, S. Apoptosis: A Review of Programmed Cell Death. Toxicologic Pathology, v. 35, n. 4, p. 495-516, 2007.

FALLON, M. et al. Management of cancer pain in adult patients: ESMO Clinical Practice Guidelines. Annals of Oncology, v. 29, n. July, p. iv166-iv191, 2018.

FAN, T. M. Pain management in veterinary patients with cancer. The Veterinary clinics of North America. Small animal practice, v. 44, n. 5, p. 989-1001, 2014.

FASTAIA, J.; DUMONT, A. E. Pathogenesis Of Ascites In Mice With Peritoneal Carcinomatosis. Journal of the National Cancer Institute, v. 56, n. 3, p. 547-550, 1976.

FERLAY, J. et al. Cancer incidence and mortality worldwide: Sources, methods and major patterns in GLOBOCAN 2012. International Journal of Cancer, v. 136, n. 5, p. E359E386, 2015.

FERNANDES, P. D. et al. Characterization of the inflammatory response during Ehrlich ascitic tumor development. Journal of Pharmacological and Toxicological Methods, v. 71, p. 83-89, 1 jan. 2015.

FRESE, K. K.; TUVESON, D. A. Maximizing mouse cancer models. Nature Reviews Cancer, v. 7, n. 9, p. 645-658, 2007.

FRIESEN, C. et al. Methadone, commonly used as maintenance medication for outpatient treatment of opioid dependence, kills leukemia cells and overcomes chemoresistance. Cancer Research, v. 68, n. 15, p. 6059-6064, 2008.

FRIESEN, C. et al. Cytotoxic effects of opioids on cancer cell lines. International Journal of Clinical Pharmacology and Therapeutics, v. 49, n. 1, p. 60-62, 2011.

FRIESEN, C. et al. Cell death sensitization of leukemia cells by opioid receptor activation. Oncotarget, v. 4, n. 5, p. 677-690, 2013.

FRIESEN, C. et al. Opioid receptor activation triggering downregulation of cAMP improves effectiveness of anti-cancer drugs in treatment of glioblastoma. Cell Cycle, v. 13, n. 10, p. 1560-1570, 2014.

FUKUMASU, H.; LATORRE, A. O.; ZAIDAN-DAGLI, M. L. Paullinia cupana Mart. var. sorbilis, guarana, increases survival of Ehrlich ascites carcinoma (EAC) bearing mice by decreasing cyclin-D1 expression and inducing a G0/G1 cell cycle arrest in EAC cells.

Phytotherapy Research, v. 25, n. 1, p. 11-16, 1 jan. 2011.

GACH, K. et al. The role of morphine in regulation of cancer cell growth. NaunynSchmiedeberg's Archives of Pharmacology, v. 384, n. 3, p. 221-230, 2011.

GAYNOR, J. S. Control of Cancer Pain in Veterinary Patients. Veterinary Clinics of North America - Small Animal Practice, v. 38, n. 6, p. 1429-1448, 2008.

GEBHART, G. Recognition and Alleviation of Pain in Laboratory Animals. Washington, 
D.C.: National Academies Press, 2009. v. 98

GEYER, M. A.; RUSSO, P. V.; MASTEN, V. L. Multivariate assessment of locomotor behavior: Pharmacological and behavioral analyses. Pharmacology, Biochemistry and Behavior, v. 25, n. 1, p. 277-288, 1986.

GRAY, J.; MCNAUGHTON, N. Gray's Neuropsychology of anxiety: An enquiry into the functions of septohippocampal theories. 2. ed. New York: Oxford University Press, 2003. v. 2

GREGORY, N. et al. An overview of animal models of pain: disease models and outcome measures. Journal of Pain, v. 11, n. 13, p. 1-26, 2013.

GRIMM, K. A. et al. Veterinary Anaesthesia and Analgesia. Veterinary Anaesthesia and Analgesia. Cambridge: Cambridge University Press, 2015. p. 1-30.

GRUNG, M. et al. Morphine-6-glucuronide-induced locomotor stimulation in mice: Role of opioid receptors. Pharmacology and Toxicology, v. 82, n. 1, p. 3-10, 1998.

GUPTA, K. et al. Morphine stimulates angiogenesis by activating proangiogenic and survival-promoting signaling and promotes breast tumor growth. Cancer research, v. 62, n. 15, p. 4491-8, 2002.

HALL, C. S. Emotional behavior in the rat. I. Defecation and urination as measures of individual differences in emotionality. Journal of Comparative Psychology, v. 18, n. 3, p. 385-403, 1934.

HARIMAYA, Y. et al. Potential ability of morphine to inhibit the adhesion, invasion and metastasis of metastatic colon 26-L5 carcinoma cells. Cancer Letters, v. 187, n. 1-2, p. 121$127,2002$.

HARTVEIT, F. The significance of the blood content of the bergen a4 mouse ascites carcinoma. British Journal of Cancer, v. 18, n. 3, p. 557-563, 1964.

HASHEM, M. A. et al. The antitumor activity of Arthrospira platensis and/or cisplatin in a murine model of Ehrlich ascites carcinoma with hematinic and hepato-renal protective action. Journal of Functional Foods, v. 66, n. 1, p. 103831, 2020.

HE, L. et al. Methadone Antinociception Is Dependent on Peripheral Opioid Receptors. Journal of Pain, v. 10, n. 4, p. 369-379, 2009.

HECHT, A.; SCHIORRING, E. Behavior Effects of Low and High Acute Doses of Morphine in Solitary Mice. Psychopharmacology, v. 64, p. 73-79, 1979.

HENGARTNER, M. O. The biochemistry of apoptosis. Nature, v. 407, n. 6805, p. 770-776, out. 2000.

HNASKO, T. S.; SOTAK, B. N.; PALMITER, R. D. Morphine reward in dopamine-deficient mice. Nature, v. 438, n. 7069, p. 854-857, 2005. 
INCA. INCA - Câncer de Mama. Disponível em:

<http://www2.inca.gov.br/wps/wcm/connect/tiposdecancer/site/home/mama/cancer_mama>. Acesso em: 19 mar. 2018.

ISHIKAWA, M. et al. Enhancement of Tumor Growth by morphine and its possible mechanism in mice. Biological and Pharmaceutical Bulletin, v. 16, n. 8, p. 762-766, 1993.

KABEER, F. A. et al. In vitro and in vivo antitumor activity of deoxyelephantopin from a potential medicinal plant Elephantopus scaber against Ehrlich ascites carcinoma. Biocatalysis and Agricultural Biotechnology, v. 19, n. 9, p. 101-106, 2019.

KITANAKA, N. et al. Tetrabenazine, a vesicular monoamine transporter-2 inhibitor, attenuates morphine-induced hyperlocomotion in mice through alteration of dopamine and 5hydroxytryptamine turnover in the cerebral cortex. Pharmacology Biochemistry and Behavior, v. 172, n. July, p. 9-16, 2018.

LAZARCZYK, M.; MATYJA, E.; LIPKOWSKI, A. W. A comparative study of morphine stimulation and biphalin inhibition of human glioblastoma T98G cell proliferation in vitro. Peptides, v. 31, n. 8, p. 1606-1612, 2010.

LIN, X. et al. Chronic high-dose morphine treatment promotes SH-SY5Y cell apoptosis via cJun N-terminal kinase-mediated activation of mitochondria-dependent pathway. FEBS Journal, v. 276, n. 7, p. 2022-2036, 2009.

LOONEY, A. Oncology Pain in Veterinary Patients. Topics in Companion Animal Medicine, v. 25, n. 1, p. 32-44, 2010.

MAKMAN, M. H. Morphine receptors in immunocytes and neurons. Advances in Neuroimmunology, v. 4, n. 2, p. 69-82, 1994.

MANTYH, P. W. Cancer pain and its impact on diagnosis, survival and quality of life. Nature Reviews Neuroscience, v. 7, n. 10, p. 797-809, out. 2006.

MATHEW, B. et al. The novel role of the mu opioid receptor in lung cancer progression: A laboratory investigation. Anesthesia and Analgesia, v. 112, n. 3, p. 558-567, 2011.

MAYER, K. D. The pathogenicity of the Ehrlich ascites tumour. British journal of experimental pathology, v. 47, n. 5, p. 537-544, 1966.

MCGOWAN, J. C. et al. Prophylactic Ketamine Attenuates Learned Fear. Neuropsychopharmacology, v. 42, n. 8, p. 1577-1589, 27 jul. 2017.

MEIER, P.; FINCH, A.; EVAN, G. <407796a0.Pdf>. v. 407, n. October, 2000.

MERCADANTE, S. Malignant bone pain: pathophysiology and treatment. Pain, v. 69, n. 12, p. 1-18, 1997.

MERCADANTE, S. et al. Methadone response in advanced cancer patients with pain followed at home. Journal of Pain \& Symptom Management, v. 18, n. 3, p. 188-192, 1999. 
MERCADANTE, S.; BRUERA, E. Methadone as first line opioid in cancer pain management: a systematic review. Journal of Pain and Symptom Management, 2017a.

MERCADANTE, S.; BRUERA, E. Methadone as a First-Line Opioid in Cancer Pain Management: A Systematic Review. Journal of Pain and Symptom Management, v. 55, n. 3, p. 998-1003, 2017b.

MIDDAUGH, L. D.; INGRAM, D. K.; REYNOLDS, M. A. Methadone effects on locomotor activity of young and aged mice. Neurobiology of Aging, v. 4, n. 2, p. 157-161, 1983.

MUNN, L. L. Cancer and inflammation. Wiley Interdisciplinary Reviews: Systems Biology and Medicine, v. 9, n. 2, 2017.

NUNEZ, R. DNA measurement and cell cycle analysis by flow cytometry. Current Issues in Molecular Biology, v. 3, n. 3, p. 67-70, 2001.

ODUNAYO, A. et al. Immunomodulatory effects of opioids. Journal of Veterinary Emergency and Critical Care, v. 20, n. 4, p. 376-385, 2010.

ONAOLAPO, J. O. et al. Caffeine and sleep-deprivation mediated changes in open-field behaviours, stress response and antioxidant status in mice. Sleep Science, v. 9, n. 3, p. 236243, 2016.

OZASLAN, M. et al. Ehrlich ascites carcinoma. African Journal of Biotechnology, v. 10, n. 13, p. 2375-2378, 2011.

PACHARINSAK, C.; BEITZ, A. J. Animal models of cancer pain. Comparative Medicine, v. 58, n. 3, p. 220-233, 2008.

PACIFICI, R. et al. Effect of morphine and methadone acute treatment on immunological activity in mice: pharmacokinetic and pharmacodynamic correlates. The Journal of pharmacology and experimental therapeutics, v. 269, p. 1112-1116, 1994.

PATTI, C. L. et al. Behavioral characterization of morphine effects on motor activity in mice. Pharmacology Biochemistry and Behavior, v. 81, n. 4, p. 923-927, ago. 2005.

POLOMANO, R. C. et al. A painful peripheral neuropathy in the rat produced by the chemotherapeutic drug, paclitaxel. Pain, v. 94, n. 3, p. 293-304, 2001.

POMORSKA, D.; GACH, K.; JANECKA, A. Immunomodulatory Effects of Endogenous and Synthetic Peptides Activating Opioid Receptors. Mini-Reviews in Medicinal Chemistry, v. 14, n. 14, p. 1148-1155, 16 fev. 2015.

ROLIM, T. L. et al. Toxicity and antitumor potential of Mesosphaerum sidifolium (Lamiaceae) oil and fenchone, its major component. BMC Complementary and Alternative Medicine, v. 17, n. 1, p. 1-12, 2017.

SACERDOTE, P. et al. The effects of tramadol and morphine on immune responses and pain after surgery in cancer patients. Anesthesia and analgesia, v. 90, n. 6, p. 1411-1414, 2000. 
SACERDOTE, P. et al. Buprenorphine and methadone maintenance treatment of heroin addicts preserves immune function. Brain, Behavior, and Immunity, v. 22, n. 4, p. 606-613, 2008 .

SALAS, Y. et al. Epidemiological study of mammary tumors in female dogs diagnosed during the period 2002-2012: A growing animal health problem. Plos One, v. 10, n. 5, p. 1$15,2015$.

SEIBENHENER, M. L.; WOOTEN, M. C. Use of the open field maze to measure locomotor and anxiety-like behavior in mice. Journal of Visualized Experiments, n. 96, p. 1-6, 2015.

SHERR, C. J. Cancer cell cycles. (Cover story). Science, v. 274, n. 5293, p. 1672, 1996.

SHUPAK, N. M. et al. Analgesic and behavioral effects of a $100 \mathrm{~m}$ T specific pulsed extremely low frequency magnetic field on control and morphine treated CF-1 mice. v. 354, p. 30-33, 2004.

SIMON, R. H.; ARBO, T. E. Morphine increases metastatic tumor growth. Brain Research Bulletin, v. 16, n. 3, p. 363-367, 1986.

SPRUIJT, B. M.; GISPEN, W. H. Behavioral sequences as an easily quantifiable parameter in experimental studies. Physiology and Behavior, v. 32, n. 5, p. 707-710, 1984.

SPRUIJT, B. M.; VAN HOOFF, J. A. R. A. M.; GISPEN, W. H. Ethology and neurobiology of grooming behavior. Physiological Reviews, v. 72, n. 3, p. 825-852, 1992.

STEIN, C.; LANG, L. J. Peripheral mechanisms of opioid analgesia. Current Opinion in Pharmacology, v. 9, n. 1, p. 3-8, 2009.

STOJANOVIĆ, N. M.; RANDJELOVIĆ, P. J.; RADULOVIĆ, N. S. Correlation between Two Parameters of Mice Behaviour in the Open Field Test. Acta Facultatis Medicae Naissensis, v. 34, n. 4, p. 321-327, 2017.

STURMAN, O.; GERMAIN, P. L.; BOHACEK, J. Exploratory rearing: a context- and stresssensitive behavior recorded in the open-field test. Stress, v. 21, n. 5, p. 443-452, 2018.

TANAKA, S. et al. Four factors underlying mouse behavior in an open field. Behavioural Brain Research, v. 233, n. 1, p. 55-61, jul. 2012.

TEGEDER, I. et al. G protein-independent G1 cell cycle block and apoptosis with morphine in adenocarcinoma cells: Involvement of p53 phosphorylation. Cancer Research, v. 63, n. 8, p. 1846-1852, 2003.

TURNER, P. V.; PANG, D. S.; LOFGREN, J. L. A Review of Pain Assessment Methods in Laboratory Rodents. Comparative medicine, v. 69, n. 6, p. 451-467, 2019.

USTUN, F. et al. Evaluation of morphine effect on tumour angiogenesis in mouse breast tumour model, EATC. Medical Oncology, v. 28, n. 4, p. 1264-1272, 2011.

VAN DEN BEUKEN-VAN EVERDINGEN, M. H. J. et al. Update on Prevalence of Pain in 
Patients with Cancer: Systematic Review and Meta-Analysis. Journal of Pain and Symptom Management, v. 51, n. 6, p. 1070- 1090.e9, 2016.

VARELA, M. J. et al. Potentiation of morphine-induced antinociception and locomotion by citalopram is accompanied by anxiolytic-like effects. Pharmacology Biochemistry and Behavior, v. 163, n. October, p. 83-89, 2017.

WALDHOER, M.; BARTLETT, S. E.; WHISTLER, J. L. Opioid Receptors. Annual Review of Biochemistry, v. 73, n. 1, p. 953-990, 2004.

WALSH, R. N.; CUMMINS, R. A. The open-field test: A critical review. Psychological Bulletin, v. 83, n. 3, p. 482-504, 1976.

WHO. Cancer - Diagnosis and Treatment. Disponível em:

<http://www.who.int/cancer/treatment/en/>. Acesso em: 15 mar. 2018.

WOLF, S. et al. Chemotherapy-induced peripheral neuropathy: Prevention and treatment strategies. European Journal of Cancer, v. 44, n. 11, p. 1507-1515, 2008.

YAKSH, T. L.; YEUNG, J. C.; RUDY, T. A. Systematic examination in the rat of brain sites sensitive to the direct application of morphine: Observation of differential effects within the periaqueductal gray. Brain Research, v. 114, n. 1, p. 83-103, set. 1976.

YEAGER, M. P.; COLACCHIO, T. A. Effect of Morphine on Growth of Metastatic Colon Cancer In Vivo. Archives of Surgery, v. 126, n. 4, p. 454-456, 1991.

YIN, D. et al. Fas-mediated cell death promoted by opioids. Nature, v. 397, n. 6716, p. 218 218, jan. 1999.

ZYLLA, D.; STEELE, G.; GUPTA, P. A systematic review of the impact of pain on overall survival in patients with cancer. Support Care Cancer, v. 25, p. 1687-1698, 2017. 


\section{APÊNDICE A}

Elidiane Rusch <elidianerusch@usp.br>

\section{Journal of the American Association for Laboratory Animal Science - Manuscript ID JAALAS-20-000053 \\ 1 mensagem}

Journal of the A merican Association for Laboratory Anim al Science

<onbehalfof@manuscriptcentral.com>

27 de abril de 2020

Responder a: journals@aalas.org

Para: carregaro@usp.br, adrianocarregaro@gmail.com

Cc: elidianerusch@usp.br, milena.bovi@usp.br, elaine.martinelli@usp.br, mari-aranha@hotmail.com, claudiam@usp.br, daniele@usp.br, carregaro@usp.br, adrianocarregaro@gmail.com

27-Apr-2020

Dear Professor Carregaro:

Your manuscript entitled "Three-day consecutive administration of morphine or methadone promotes antinociception and increases behavioural activity in mice with Ehrlich carcinoma" has been successfully submitted online and is presently being given full consideration for publication in the Journal of the American Association for Laboratory Animal Science.

Your manuscript ID is JAALAS-20-000053

Please mention the above manuscript ID in all future correspondence or when calling the office for questions. If there are any changes in your street address or e-mail address, please log in to Manuscript Central at https://mc. manuscriptcentral.com/aalas-jaalas and edit your user information asappropriate.

You can also view the status of your manuscript at any time by checking your Author Center after logging in to https://mc. manuscriptcentral.com/aalas-jaalas.

Thank you for submitting your manuscript to the Journal of the American Association for Laboratory Animal Science.

Sincerely,

Journal of the American Association for Laboratory Animal Science Editorial Office 